\title{
Aspek Perlindungan Hukum Nasabah dalam Sistem Pembayaran Internet
}

\author{
Budi Agus Riswandi
}

\begin{abstract}
The problem of legal security and certainty is a negative effect of e-commerce development. The efforts to give legal protection to customers can be done by using The Most Characteristic Connection Theory. Indonesian contract law can only be applied if the suppliers of internet payment service are in Indonesia. In spite of the fact that Indonesian authentication law has been unfamiliar with digital signature as written evidence, the emerging controversy can be settled by using conventional ADR or online ADR agency.
\end{abstract}

\section{Pendahuluan}

Salah satu karakter bisnis yang paling menonjol pada era globalisasi adalah moving. quickly. William Irwin Thompson mengatakan bahwa perubahan yang sangat cepat didukung oleh teknologi dan informasi, tidak lagi menghitung abad, tahun dan bulan, tetapi pergeseran dan perubahan biasa terjadi setiap hari, now with the appearance of microelectronic and genetic engineering; a change that spells a movement from evolution by natural selection by cultural instrusion, the rate of change shift to decades, even years. ${ }^{1}$

'Perubahan dan pergeseran yang cepat dalam era super industrialisasi sekarang, telah mengantar umat manusia ke dalam suatu kehidupan "dunia tanpa batas". (borderless world) dalam suatu kegiatan interlinked economy. Keadaan inilah yang digambarkan John Naisbitt tentang perubahan yang dihadapi manusia. Dunia dihuni manusia telah berubah menjadi global village (perkampungan global) dengan sistem perekonomian single economy. Dikatakan, the world moving from trade countries to a single economy, one economy, one market place.

Dalam konteks perdagangan internasional oleh Carolyn Hotchkiss dikatakan political boundaries don't define market boundaries anymore. Businesses are trading and making investments wherever they think they can get a competitive adventage. Dukungan terhadap pendapat ini juga datang dari Daniels Davidson yang mengatakan we are so economiclly interdependent on one another that we do live in global village. William Irwin Thompson. 1985. Pasific Shelf. San Fransisco: Series Club Books. Hlm. 4. Lihat Keinichi Ohmae. 1990. Bonderless World. USA: Business Maknisey Company Printed. HIm. XII. Lihat juga John Naisbitt. 1990. Megatrend 2000, Great Britain: Pan Book Published. HIm. 12. Lihat juga Carolyn Hotchkiss. 1994. Interna- 
Hadirnya masyarakat informasi (information society) $^{2}$ yang diyakini sebagai salah satu agenda penting masyarakat dunia pada milenium ketiga antara lain ditandai dengan pemanfaatan internet yang semakin meluas dalam berbagai aktivitas kehidupan manusia, bukan saja di negara-negara maju tapi juga di negara-negara berkembang termasuk Indonesia. Fenomena ini pada gilirannya telah menempatkan informasi sebagai komoditas ekonomi yang sangat penting dan menguntungkan. Untuk merespon perkembangan ini Amerika Serikat sebagai pioner dalam pemanfaatan internet telah mengubah paradigma ekonominya dari ekonomi yang berbasis manufaktur menjadi ekonomi yang berbasis jasa (form a manufacturing-based economy to a service-based economy). ${ }^{3}$
Eksistensi Internet ${ }^{4}$ sebagai salah satu institusi dalam mainstream budaya Amerika lebih ditegaskan lagi dengan maraknya perdagangan èlektronik (e-commèrce) yang diprediksikan sebagai bisnis besar masa depan (the next big thing). Menurut perkiraan Departemen Perdagangan Amerika Serikat, nilai perdagangan sektor ini sampai dengan tahun 2002 akan mencapai jumlah US $\$ 300$ milyar per tahun. Demam e-commerce ini tidak saja telah melanda negara-negara maju seperti Amerika Serikat dan negara-negara Eropa, tapi juga telah menjadi trend dunia termasuk indonesia. ${ }^{5}$

Perkembangan e-commerce membawa banyak perubahan terhadap sektor aktivitas bisnis yang selama ini dijalankan di dunia riil. Perubahan tersebut ditandai dengan adanya sejumlah upaya dari sektor aktivitas bisnis

tional Law For Business, International Edition, Mc. Graw Hill: Business Law Series. Him. 4. Lihatjuga Daniels Davidson.1997. Comprehensive Business Law. Boston Massachusets: Ken Publishing Comp. HIm. 123.

${ }^{2}$ Menurut Alfin Tofler teknologi selalu jadi penggerak utama segala macam perubahan. Ada tiga tahapan perubahan akibat perkembangan teknologi, yakni; era pertanian, era perindustrian, dan era informasi. Harian Bisnis Indonesia. Tanggal 19 Oktober 2000.

${ }^{3}$ Atip Latifulhayat. "Cyber Law dan Urgensinya Bagi Indonesia." Makalah disampaikan pada seminar tentang Cyber Law. Diselenggarakan oleh Yayasan Cipta Bangsa. Bandung. Tanggal $29 \mathrm{Juli} 2000$. HIm. 1

${ }^{4} \mathrm{Komunikasi} \mathrm{komputer} \mathrm{pernah} \mathrm{terbatas} \mathrm{untuk} \mathrm{penggunaan} \mathrm{komputer} \mathrm{yang} \mathrm{sama.} \mathrm{Munculnya} \mathrm{jaringan} \mathrm{kerja}$ (network) telah memungkinkan para pengguna untuk berkomunikasi satu sama lain dalam perusahaan yang sama maupun antara perusahaan di seluruh dunia. DI banyaknegara pengetahuan TI tidak lagi terbatas untuk kalangan profesional yang terlatih secara khusus, tetapi sekarang jauh lebih luas, terutama di antara generasi yang lebih muda. Pada tingkat politik, masyarakat tidak pernah mempunyai akses yang.begitu bebas terhadap dunia luar, baik melalui telepon ataupun jaringan komputer. Jaringan internet, yang menjangkau banyak negara, sekarang mempunyai 20 juta pemakai yang tersambung padanya, termasuk di dalamnya Gedung Putih. Artinya kendali politis atas aliran informasi menjadi semakin sulit. Walaupun pertumbuhan seperti itu dalam pertukaran informasi menghadirkan masalah bagi para politisi, tetapi itu juga menawarkan manfaat potensial yang signifikan kepada mereka dan negara mereka. Lihat Joe Peppard \& Philip Rowland. The Essence of Business Process Re-Engineeiring. Yogyakarta: Andi Yogyakarta. HIm. 161-162.

${ }^{5}$ lbid. 
yang semula berbasis di dunia riil, kemudian mengembangkannya ke dunia maya. Salah satu sektor bisnis itu adalah berkaitan dengan sektor perbankan yang dikenal dengan istilah e-banking.

Implikasi dari pengembangan ini dirasa ada sisi positif dan negatif. Aspek positifnya bahwa dengan pengembangan kegiatan perbankan di internet melalui jaringan online, telah meningkatkan peranan dan fungsi perbankan itu sendiri sebagai lembaga intermediari sekaligus memberikan kemudahan dan efisiensi bagi para pengguna jasa e-banking. Aspek negatif dari pengembangan ini adalah berkaitan dengan persoalan keamanan dalam bertransaksi dengan menggunakan media ebanking dan secara yuridis terkait pula dengan jaminan kepastian hukum (legal certainty).

Masalah keamanan ini masih menjadi masalah dalam internet. Aspek-aspek yang dipermasalahkan itu antara lain: ${ }^{6}$

a. Masalah kerahasiaan (confidentiality) pesan. Diasumsikan bahwa setiap kali mengirim pesan di internet, sama halnya seperti menggunakan media kartu pos di mana semua orang dapat membacanya. Tentunya tidak ingin orang yang tidak berkepentingan membaca pesan yang dikirim itu.

b. Masalah bagaimana cara agar pesan yang dikirimkan itu keutuhannya (integrity) sampai ke tangan penerima. Di intemet, orang lain dapat mengubah isi pesan yang dikirimkan itu, atau mengganti sama sekali pesan itu.
Sesuatu yang tidak diinginkan apabila ada tangan usil yang bisa mengubah transaksi bernilai Rp. 10.000,menjadi Rp. 100.000,- saat data transaksi dikirimkan melalui internet.

c. Masalah keabsahan (authenticity) pelaku transaksi. Bagaimana seorang pembeli yakin bahwa sang penjual benar-benar otentik alias bukan seorang penipu? Dalam kehidupan seharihari bisa dengan mudah dilakukan proses otentikasi terhadap kedua orang tua dengan cara melihat muka mereka, bahkan mungkin cukup dengan suara mereka saja. Tapi bagaimana cara mengetahui ibu_dibyo@cyberticketsco.id adalah benar-benar Ibu Dibyo yang biasa menjual tiket-tiket konser? Siapa saja dapat membuat toko di internet, dan meminta konsumen untuk memasukkan data kartu kreditnya. Bisa saja toko itu tidak pernah mengirim pesan sang pembeli, karena memang pemilik toko tersebut beriktikad buruk. Di sisi lain bagaimana pedagang bisa yakin bahwa pembeli tidak menyalahgunakan identitas dan nomor kartu kredit orang lain?

d. Masalah keaslian pesan agar bisa dijadikan barang bukti. Seorang konsumen tentu tidak ingin kalau ditagih bank untuk pembelian dua untai kalung Berlian yang tidak pernah dibelinya, meskipun bank mengaku menyimpan data transaksi tersebut. $\mathrm{Di}$

${ }^{6}$ Arrianto Mukti Wibowo. "Studi Perbandingan Sistem-Sistem Perdagangan DI Internet dan Desain Protokol Cek Bilyet Digital. "Laporan Penelitian. Fakultas IImu Komputer Ul. Jakarta. 1997. HIm. 3. 
sisi lain jika ternyata nasabah memang membeli perhiasanperhiasan tersebut, harus ada mekanisme tertentu sehingga nasabah tidak dapat menyangkal bahwa dia telah membeli perhiasanperhiasan tersebut.

Dalam industri perbankan banyak sekali pihak-pihak yang terkait, di antaranya: direksi bank, nasabah, dan karyawan. Untuk pemanfaatan intemet sebagai jaringan online bagi kegiatan di sektor perbankan pihak nasabah merupakan salah satu pihak yang perlu mendapatkan perhatian dan perlindungan hukum dalam transaksi pembayaran e-banking.

$\mathrm{Hal}$ ini sangat diperlukan mengingat transaksi pembayaran e-banking sangat berbeda dengan sistem yang dilakukan di sektor perbankan biasa. Dalam pelaksanaannya transaksi pembayaran e-banking seluruh dokumen umumnya sifatnya elektronik, penandatanganan juga bersifat elektronik (digital signature) dan proses transaksi itu sendiri bersifat online. Artinya pihak yang bertransaksi tidak bertemu secara langsung.

Jadi, kekhawatiran kurangnya perlindungan hukum terhadap nasabah dalam transaksi pembayaran e-banking masih besar kemungkinannya. Apalagi biasanya mereka yang melakukan transaksi pembayaran e-banking jumlahnya ribuan dan dapat dilakukan antar negara bahkan benua.

Dari segi hukum ini menjadi persoalan tersendiri. Beberapa permasalahan hukum yang muncul dalam sistem pembayaran internet, di antaranya: Pertama, keabsahan dari kontrak itu sendiri yang dilakukan dengan menggunakan media elektronik. Kedua, pengakuan terhadap digital signature sebagai alat bukti yang sah. Ketiga, upaya penyelesaian hukum di antara para pihak jika terjadi sengketa. Ketiganya ini sangat relevan apabila dikaitkan dengan aspek perlindungan hukum bagi nasabah pengguna jasa pembayaran melalui internet.

Beberapa peraturan perundang-undangan indonesia ternyata belum dapat mencakup dan mengantisipasi seluruh permasalahan di atas. $\mathrm{Hal}$ ini terjadi disebabkan ketentuan perundang-undangan Indonesia masih dibatasi adanya yurisdiksi, sementara dalam internet sendiri pihak-pihak yang bertransaksi sangat beragam dan terdiri dari berbagai suku, negara dan benua. Dalam hal hukum kontrak pun juga masih banyak permasalahan. Contoh permasalahannya ketika seseorang melakukan transaksi perdagangan melalui internet sangat sulit diidentifikasi apakah seseorang itu cakap melakukan perbuatan hukum atau tidak. Sebab di internet sendiri dalam bertransaksi para pihak tidak berhadapan langsung. Di samping itu masalah keabsahan alat bukti yang ada di media internet semuanya cenderung elektronis, sementara hukum Indonesia mensyaratkan bahwa alat bukti harusnya bersifat tertulis. Di sisi lain dengan pesatnya perkembangan teknologi baru hukum sangat sulit untuk menyesuaikan dengan perkembangan tersebut.

Berdasarkan uraian di atas, tulisan ini akan memfokuskan diri pada tiga permasalahan pokok, yakni; Pertama, bagaimana pelaksanaan kontrak dalam transaksi pembayaran internet dengan menggunakan media elektronik? Kedua, apakah digital signature dapat dijadikan alat bukti sah? Ketiga, bagaimana upaya penyelesaian hukum apabila terjadi sengketa dalam sistem pembayaran internet? 


\section{Aspek Perlindungan Hukum dalam Sistem Pembayaran Internet}

Thomas Friedman dalam bukunya The Lexus and Olive Tree menyatakan inovasi yang terjadi dalam komputerisasi, miniaturisasi dan digitalisasi telah mendemokratisasikan teknologi secara keseluruhan. Artinya semua penemuan ini memungkinkan jutaan orang di mana saja di dunia untuk terkoneksi dan saling tukar informasi, berita, uang, foto keluarga, perdagangan, finansial, musik, atau acara televisi sedemikian rupa dan pada tingkatan yang tidak pernah disaksikan sebelumnya. ${ }^{\text {? }}$

Banyak orang percaya bahwa semuanya ini merupakan adegan babak awal ekonomi baru berbasis internet. Penyebaran internet telah membawa berbagai manfaat dan peluang ke masyarakat pelanggan dan perusahaan suatu negara, terutama dalam memacu pertumbuhan ekonomi dan lapangan kerja, pengembangan pasar yang lebih kompetitif, penghematan biaya dan penyederhanaan pelayanan jasa. Internet juga menciptakan model bisnis baru yang mengubah dasar-dasar ekonomi usaha dan menurunkan jam biaya transaksi. Misalnya jasa perbankan di Amerika Serikat telah menurun dari satu dollar AS menjadi satu sen dollar AS. ${ }^{8}$
Dengan semakin berkembangnya dunia internet dan e-commerce, tidak saja membawa implikasi pada aspek ekonomi tetapi juga pada aspek hukum. Sebelum menjelaskan mengenai perlindungan hukum bagi nasabah dalam sistem pembayaran internet, di mana dalam praktiknya, bagaimana mengaplikasikan hukum baik yang tradisional maupun yang baru ke dalam teknologi baru guna memberikan jaminan hukum bagi pengguna teknologi ini. Ada baiknya apabila pembahasan-nya dimulai dulu dengan memaparkan keterkaitan antara teknologi baru dengan hukum dan hal ini dapatlah kiranya sebagai alat bantu/bahan pengalaman untuk menganalisis penerapan hukum ke dalam teknologi tersebut.

Pada kesempatan ini akan diambil sebuah contoh yang terjadi di Amerika Serikat sebagai negara pelopor pertama dalam pengembangan teknologi internet sekaligus juga menyangkut masalah pengaturan teknologi internet ke dalam sistem hukumnya.

Di Amerika Serikat, masalah mengenai bagaimana pengaruh hukum terhadap teknologi baru ini dan para pelaku bisnis di bidang ini yang tumbuh dengan cepat. Hal ini bukanlah isu yang enteng. Sangat jelas jika tidak semua yang dianggap ilegal secara offline juga harus ilegal pula bila berada secara online. Kesemuanya ini acapkali lembaga legislatif menggunakan hukum yang

"Maksud dari yang "belum pernah disaksikan sebelumnya" dapat dicontohkan bahwa di era internet/digital ini, maka jika seseorang wartawan Times menggunakan kamera digital, memotret peristiwa kerusuhan di sampit (Kallim) dan kemudian memasukannya ke dalam disket dan mengeditnya di komputer, lalu mengirimnya secara digital melaluijaringan intemet, maka redaksi Times dalam waktu beberapa jam atau,kurang lebih 10 jam akan dapat dengan cepat melihat photo tersebut di Hongkong. Rene L. Pattiradjawane. "Globalisasi dan Teknologi



${ }^{8}$ Darwin Silalahi. "Banyak Negara Bersiap dengan Ekonomi Berbasis Internet." Harian Kompas. Tanggal 10 April 2000. 
ada dengan membuat beberapa penyesuaian yang dapat diaplikasikan dengan kondisi di internet. Tindakan seperti ini memerlukan usaha untuk membaca ulang secara hati-hati hukum yang ada dan pemahaman yang jelas mengenai teknologi baru dan model bisnis baru ini. Terkadang karena kurang kerasnya usaha lembaga legislatif dalam memahami hukum akan mengakibatkan suatu kekaburan pandangan mengenai hukum terhadap teknologi baru ini. Inilah mengapa industri yang terkait dengan masalah ini harus lebih memfokuskan perhatiannya terhadap aktivitasaktivitas legislatif.

Hukum yang sekarang berlaku telah ditulis Aama sebelum teknologi yang sekarang berkembang muncul dalam sebuah pemikiran. Bahasa yang dulunya-cocok dengan teknologi -lama belum tentu cocok juga dengan teknologi terbaru. Sebagai contoh, banyak dari hukum perlindungan konsumen yang mengharuskan suatu tipe ukuran yang spesifik untuk setiap "keluhan/pemberitahuan yang disampaikan. Persyaratan-persyaratan ini telah ditulis lama Jada saat setiap bentuk pemiberitahuan tertulis jada secarik kertas, tetapi tidak diterjemahkan Jengan baik untuk dokumen elektronik, seperti website atau penampil text berlayar kecil seperti telepon seluler, di mana para penggunanya tidak dapat menjelaskan secara spesifik ukuran tampilannya maupun ukuran glat terșebut. Lembaga legislatif tidak hanya jerlu menghindari kesalahan seperti ini saja, etapi hukum yang sekarang berlaku sangat jerlu diperbaharui. Solusinya adalah agar persyaratan-persyaratan yang ada harus lebih jelas dan kentara - mungkin saja tidak harus tersurat tetapi harus memenuhi standar fleksibilitas. Menyatu dengan definisi kejelasan tadi yang di dalamnya tertera standar yang dapat sesuai dengan teknologi baru, di mana hukum dapat dilaksanakan secara benar.

Hukum dapat juga dipengaruhi oleh ketakutan akan teknologi baru. Sebuah kasus yang menekankan pada peraturan E-Sign terbaru federal, yang mana termasuk ketentuanketentuan yang menerapkan standar untuk ecommerce yang tidak diterapkan pada paper commerce (bentuk usaha konvensional). Di dalam persoalan ini, Senator Gramm beberapa waktu yang lalu mengeluarkan pernyataan:9

"Bagi mereka yang merasa takut/ terganggu dengan adanya pasar elektronik, dan bagi mereka yang merasa gentar bertemu dengan ekspresi yang mungkin muncul dalam debat dalam pertemuan komite. Nantinya dalam pertemuan komite ini akan diputuskan suatu ketentuan sebagai rancangan undang-undang yang mana dapat digunakan sebagai standar e-commerce bukan untuk paper commerce. Setiap teknologi maju pastilah akan menemui banyak rintangan sebelum keuntungan yang ditimbulkan dapat dirasakan secara luas. Sepertinya memang agak ganjil, tetapi lebih dari seratus tahun lalu telah terjadi suatu debat di kongres tentang sisi keamanan bagi pembelian mobil untuk tumpangan para presiden. Banyak suara

"Kave Caldwell. "Applying Old Law to New Technology." the CommerceNet Newsletter The Public oolicy Report. Vol. 2 No. 7 Agustus 2000. 
yang menentang jika penggunaan mobil sebagai alat transportasi presiden tidaklah aman, akan sangat berbahaya jika transportasi presiden bukan berupa kereta Kuda. Pemerintah pada akhirnya memutuskan untuk membatasi penggunaan kendaraan bermotor yang jika sekarang sangatlah lucu. Kenyataannya, banyak dari peraturan-peraturan tersebut yang tidak mungkin dilaksanakan lagi sekarang. Karena itulah saya dengan hormat meminta agar dewan legislatif memperbolehkan para pelaksana ini untuk mengabaikan beberapa aturan yang tidak sesuai seandainya kekhawatiran-kekhawatiran yang ada temyata tidak ditemukan. Electronic commerce memang sudah seharusnya diatur dengan peraturan yang memiliki fleksibilitas batasan, karena bagaimanapun juga hal ini mau tidak mau akan menjadi sistem dari abad ke-21."

Di dalam E-Sign Act, kongres secara bijaksana menyediakan kemungkinan untuk mempelajari lebih lanjut, dan mengijinkan adanya perubahan, atas ketentuan-ketentuan yang terdapat di dalam rancangan undangundang:(RUU), yang dilakukan oleh Departemen Perdagangan dan Perindustrian (Department of Commerce and Federal Trade Commission), yang mana masukannya dapat diperoleh dari masyarakat, perwakilan konsumen, dan pembisnis e-commerce. ${ }^{10}$
Bagaimanapun juga, hukum yang ada sekarang tidak selalu secermat E-Sign ini karena adanya kenyataan yang menunjukkan kekhawatiran akan teknologi bảru. Begitu kekhawatiran-kekhawatiran ini mulai mereda karena pengaruh waktu, maka peraturanperaturan ini menjadi kuno: Jika peraturanperaturan ini tidak segera diganti, dan upaya merevisi hukum terhadap teknologi baru terlambat dilakșanakan, maka peraturanperaturan lama ini nantinya akan menjadi problema tersendiri. Sebuah contoh akan keterlambatan revisi peraturan adalah pada peraturan mengenai TV Cable di California. Sepertinya ketika peraturan untuk pertama kalinya ditetapkan terdapat kekhawatiran akan pemanfaatan peralatan TV Cabel ini untuk kegiatan mata-mata atas aktivitas-aktivitas yang dilakukan di dalam rumah. Peraturan tersebut menyatakan:"

"Tidak seorangpun yang memiliki, mengkontrol, mengoperasikan ataupun mengatur perusahaan TV Cable, atau siapa saja yang menyewakan channel padahal sebuah sistem cable harus menggunakan peralatan elektronis untuk merekam, mengirim, atau mengamati setiap kejadian ataupun mèndengarkan, merekam, atau memonitor setiap percakapan yang terjadi di dalam rumah si pelanggan, tempat kerja, ataupun tempat usahanya, tanpa adanya ijin tertulis dari si pelanggan sendiri."

${ }^{\text {to }}$ Sebaiknya perusahaan-perusahaan yang bergerak di bidang e-commerce ini menyediakan layanan konsumen yang memungkinkan mereka menyampaikan pendapat yang mana pendapat mereka ini akan langsung dikirimkan kepada negara sehingga negara mengetahui sebenarnya apa yang mereka rasakan selama diberikan terus menerus dengan peraturan-peraturan pemeritah.

$"$ Ibid. 
Usaha untuk memperbaiki Cable Television Act agar dapat sesuai dengan teknologi baru yang menyangkut masalah layanan video juga menghadapi permasalahan berat ketika TV Cable ditunjuk sebagai efek dari bahasa pada ISP yang juga menyediakan layanan video. Internet, yang tidak seperti cable, adalah sebuah teknologi interaktif, yang berfungsi melalui merekam, mengirimkan suatu peristiwa yang terjadi di dalam rumah si pelanggan - sebagaimana para pengguna grafical interface menyebutnya dengan "evendriven". Klik mouse, memasukkan pilihan isi yang ingin dilihat, termasuk juga penggunaan internet telephon (yang mengharuskan perekaman percakapan) akan berubah menjadi ilegal bila peraturan lama yang saat ini masih dilaksanakan atas layanan video yang terjadi di Internet. Sementara itu industri internet bekerja dengan rajinnya untuk mencoba merevisi bahasanya sehingga dapat mudah untuk dimengerti yang tadinya dianggap sebagai pekerjaan yang tidak mungkin. Belakangan diketahui amandemen yang diajukan ternyata ditolak karena pemimpin anggota Dewan California Marco Firebugh, yang menghalangi dibuatnya undang-undang ketika industri internet saat itu mengalami kegagalan dalam membuat bahasanya dapat dipahami. ${ }^{12}$

Permasalahan lain yang timbul di dalam melaksanakan peraturan lama terhadap teknologi baru terjadi ketika lembaga legislatif mengusulkan untuk memperluas bagian dari peraturan yang sudah ada dan menambahkan pernyataan jika peraturan ini berlaku untuk semua bentuk internet. Hal ini memang benar adanya akan hukum perlindungan konsumen, yang cenderung untuk mengkhususkan target atas berbagai jenis praktik yang telah diatur oleh législatif selama bertahun-tahun. Sementara itu prinsip umum atas tindakan tidak sah secara offline harus juga merupakan tindakan tidak sah pula di online seolah sangat masuk akal, secara praktiknya untuk memperluas bagian dari peraturan di internet sangatlah tidak mungkin untuk dilakukan. Setiap bagian dari peraturan yang berlaku harus dianalisis untuk mendeterminasikan apakah peraturan ini sudah cukup cocok untuk diaplikasikan di internet. Persoalan ini, untuk wilayah California menjadi penting. Sebab di California pernah terjadi ada sebuah peraturan yang memperbolehkan class action untuk menuntut jika terdapat pelanggaran atas peraturan yang lain, walaupun si pengacara melakukan tuntutan tersebut tidak memiliki seorang klien yang secara nyata telah dirugikan. Sebagai contoh, beberapa tahun yang lalu, tuntutan yang dilakukan oleh class action melawan sebuah perusahaan software yang secara terang-terangan melanggar produk lain di mana nilai dari paket individual ditentukan berdasar isinya. Perusahaan tersebut kemudian dituntut, oleh sebuah class action, karena isi dari paket yang diberikan tidak penuh mengisi kardusnya. (2) Situasi tersebut, kemudian diperbaiki dengan merevisi peraturan agar lebih hati-hati dalam menulisnya. Sementara itu, beberapa perusahaan harus membayar biaya pengadilan yang sangat besar. Batasan waktu penggunaan peraturan lama atas internet akan menimbulkan kemungkinan sengketa class 
action yang tidak adil dan hal ini hanya akan menimbulkan permasalahan satu lagi. Jika pemerintah memang akan melakukan revisi atas peraturan lama yang akan digunakan pada internet, akan lebih baik jika merevisi setiap bagian yang cukup masuk akal, daripada melakukan revisi secara keseluruhan atas legislative act dengan sekedar melakukan pernyataan yang terkait dengan internet.

Contoh spesifik atas apa yang terjadi di California, di mana undang-undang tersebut diamandemenkan pada tahun 1998 menyatakan:13

"Setiap bentuk solicitation, transaksi atau komunikasi lain yang dilakukan melalui internet, seperti yang didefiniskan pada Section 17538, dibiarkan tetap tidak sah jika dianggap tidak sah menurut Chapter 5 (terkait dengan Section 17200), atau, Chapter 6,5 (terkait dengan Section 17350), Chapter 7 (terkait dengan Section 17360) dari Part 3, untuk solicitation, transaksi atau semua bentuk komunikasi yang dilakukan secara pribadi, melalui email, melalui telephon atau dengan menggunakan alat komunikasi lainnya."

Setelah membaca bagian yang tertera dari peraturan yang ada, muncul berbagai macam kesulitan karena sebagian besar dari peraturan ini hanya menangani praktik-praktik tertentu. Dengan mengatakan jika praktikpraktik tersebut dapat dianggap ilegal di internet, maka akan sangat penting untuk menafsirkan ulang bagian yang tertulis jauh sebelum internet lahir, dengan maksud agar peraturan ini dapat langsung diaplikasikan di internet.
Masalah lain yang muncul adalah pihak legislator, menekankan beberapa isu atas praktik-praktik tertentu di intemét yang dilakukan oleh para aktivis konsumen, membuat undangundang yang membatasi praktik-praktik tersebut, tanpa menyadari, peraturan-peraturan tersebut telah didesain untuk membatasi praktik-praktik offline yang telah dilaksanakan menurut undang-undang. Teknologi baru dapat lebih memperhatikan lagi pada masalahmasalah yang sebelumnya pemah mengemuka. Setidaknya seorang pelaku hukum telah menyatakan jika pemisahan kekuatan doktrin berarti terserah dari pengadilan yang akan memutuskan secara konstitusional (yang memang benar) dan pihak legislatif dapat mengabaikan keputusan itu (yang sangat menakutkan). Kesenjangan keputusan konstitusional atas peraturan yang diajukan nantinya hanya akan mengarah pada persengketaan yang lebih besar, seharusnya setiap isu secara konsisten harus diselesaikan setiap peraturan yang tidak sesuai telah berakhir.

Dengan menempatkan peraturan lama pada internet seolah sebuah doktrin yang memang harus dilaksanakan, tetapi dalam praktiknya hal seperti ini membutuhkan usaha yang besar untuk menghindari menciptakan hukum yang tidak becus dari intrepretasi yang sangat berarti ketika diaplikasikan pada instansi tertentu dan harus sangat mungkin untuk diaplikasikan dengan baik pada sengketa yang tidak adil.

Dengan melihat pada perkembangan penerapan hukum di Amerika Serikat terhadap teknologi baru, maka dapat ditarik kesimpulan bahwa penerapan hukum di Amerika Serikat

\section{${ }^{13}$ Ibid}


pun sebagai basis pengembangan internet, ternyata tidak melakukannya dengan sekaligus membuat hukum baru, tetapi caranya tidak lain dengan cara bertahap. Artinya hukum yang lama tetap diterapkan yang disesuaikan dengan perkembangan teknologi baru, di šisi lain hukum teknologi yang baru apabila sulit disesuaikan dengan hukum lama, maka dibuatlah hukum baru.

Pendapat ini diperkuat dengan munculnya tiga pendapat hukum yang berkembang berkaitan dengan penerapan hukum internet. Pendapat pertama secara total menolak setiap usaha untuk membuat aturan hukum bagi aktivitas-aktivitas di internet yang didasarkan atas sistem hukum tradisional/ konvensional. Mereka beralasan bahwa internet yang layaknya sebuah surga demokrasi (democratic paradise) yang menyajikan wahana bagi adanya lalu-lintas ide secara bebas dan terbuka tidak boleh dihambat dengan aturan yang didasarkan atas sistem hukum tradisional yang bertumpu pada batasan-batasan teritorial. Dengan pendirian seperti ini, maka menurut pendapat ini internet harus diatur sepenuhnya oleh sistem hukum baru yang didasarkan atas norma-norma hukum yang baru. pula yang dianggap sesuai dengan karakteristik yang melekat pada internet. Kelemahan utama dari kelompok ini adalah mereka menafikan fakta, meskipun aktivitas internet itu sepenuhnya beroperasi secara virtual, namun masih tetap melibatkan masyarakat (manusia) yang hidup di dunia maya.

Sebaliknya, pendapat kedua berpendapat bahwa penerapan sistem hukum tradisional untuk mengatur aktivitas-aktivitas di internet sangat mendesak untuk dilakukan, tanpa harus menunggu akhir dari suatu perdebatan akademis mengenai sistem hukum yang paling pas untuk mengatur aktivitas di internet. Pertimbangan pragmatis yang didasarkan atas meluasnya akibat yang ditimbulkan oleh internet memaksa untuk segera membentuk aturạn hukum mengenai hal tersebut. Untuk itu semua yang paling mungkin adalah dengan mengaplikasikan sistem hukum tradisional yang saat ini berlaku. Kelemahan utama pendapat ini merupakan kebalikan dari pendapat pertama yaitu mereka menafikan fakta bahwa aktivitas-aktivitas di internet menyajikan realitas dan persoalan baru yang merupakan fenomena. khas masyarakat informasi yang tidak sepenuhnya dapat direspon oleh sistem hukum tradisional.

Pendapat ketiga tampaknya merupakan sintesis dari kedua pendapat di atas. Mereka berpendapat bahwa aturan hukum yang mengatur mengenai aktivitas di internet harus dibentuk. secara evolutif dengan cara menerapkan prinsip-prinsip common law yang dilakukan secara hati-hati dan dengan menitikberatkan kepada aspek-aspek tertentu dalam aktivitas cyberspace yang menyebabkan kekhasan dalam transaksi-transaksi di internet. Pendapat ini memiliki pendirian cukup moderat dan realistis, karena memang ada beberapa prinsip hukum tradisional yang masih dapat merespon persoalan hukum yang timbul dari aktivitas internet di samping juga fakta bahwa beberapa transaksi di internet tidak dapat sepenuhnya direspon oleh sistem hukum tradisional.

Berdasarkan pada pendapat-pendapät ini analisis yang akan dilakukan berkaitan dengan tiga permasalahan hukum yang dikaji dalam perlindungan hukum bagi nasabah dalam sistem pembayaran internet, maka polanya akan memakai pada pendapat yang ketiga. 


\section{Pelaksanaan Kontrak Pembayaran Elektronik}

-Padà prinsipnya kontrak adalah serangkaian' janji yang dibuat parà pihak dalam kontrak. Kontrak adalah janji (promises). Atas dasar itu, Subekti ${ }^{14}$ mendefinisikan kontrak sebagai peristiwa di mana seseorang berjanji kepada orang lain atau di mana dua orang saling berjanji untuk melaksanakan sesuatu.

Janji sendiri merupakan pernyataan yang dibuat oleh seseorang kepada orang lain yang menyatakan suatu keadaan tertentu dari affair exist, atau akan melakukan suatu perbuatan tertentu. ${ }^{15}$ Orang terikat pada janjinya sendiri, yakni janji yang diberikan kepada pihak lain dalam perjanjian. Janji itu mengikat dan janji itu menimbulkan utang yang harus dipenuhi. ${ }^{16}$

Bab II Buku III Kitab Undang-Undang Hukum Perdata (KUHPerdata) Indonesia menyamakan kontrak dengan perjanjian atau persetujuan. Hal tersebut secara jelas terlihat dalam judul Bab II Buku III KUHPerdarta, yakni "Perikatan yang Lahir dari Kontrak atau Persetujuan.

Pasal 1313 KUHPerdata menyatakan bahwa perjanjian adalah suatu perbuatan dengan mana satu orang atau lebih mengikatkan dirinya terhadap satu orang atau lebih lainnya. Pengertian perjanjian yang diberikan oleh ketentuan ini ternyata mempunyai kelemahan. Menurut Abdul Kadir Muhammad kelemahan-kelemahan itu antara lain meliputi: $:^{17}$

1. Hanya menyangkut sepihak saja. Hal ini diketahui dari perumusan "satu orang atau lebih mengikatkan dirinya terhadap satu orang atau lebih lainnya." Kata kerja mengikatkan sifatnya hanya datang dari satu pihak saja, tidak dari kedua belah pihak. Seharusnya perumusan itu "saling mengikatkan diri." Jadi ada konsensus antara pihak-pinak.

2. Kata perbuatan mencakup juga tanpa konsensus. Dalam pengertian "perbuatan" termasuk juga tindakan melaksanakan tugas tanpa kuasa (zaakwaameming), tindakan melawan hukum (onrechtmatige daad) yang tidak mengandung suatu konsensus. Seharusnya dipakai kata persetujuan.

3. Pengertian perjanjian terlalu luas. Pengertian perjanjian dalam pasal tersebut terlalu luas, karena mencakup juga pelangsungan perkawinan, janji kawin, yang diatur dalam lapangan hukum keluarga. Padahal yang dimaksud adalah hubungan antara debitur dan kreditur dalam lapangan harta kekayaan saja. Perjanjian yang dikehendaki oleh buku ketiga

${ }^{14}$ Subekti. 1984. Hukum Perjanjian. Jakarta: Intremasa. HIm 36.

${ }^{15}$ A.G. Guest, (ed). 1979. Anson's law of Contract. Oxford:Clarendon Press. HIm 2.

${ }^{16} \mathrm{~J}$. Satrio. 1995. Hukum Perikatan, Perikatan yang Lahir dari Perjanjian, Buku II. Bandung: Citra Aditya Bakti. HIm 146.

${ }^{17}$ Abdul Kadir Muhammad. 1992. Hukum Perikatan. Bandung: Citra Aditya Bakti. HIm. 78. Lihat juga Meriam Darus Badrulzaman. 1994. Aneka Hukum Bisnis. Bandung: Alumni. HIm. 18. 
KUHPerdata sebenarnya hanyalah perjanjian yang bersifat kebendaan, bukan perjanjian yang bersifat personal.

4. Tanpa menyebut tujuan. Dalam perumusan pasal itu tidak disebutkan tujuan mengadakan perjanjian, sehingga pihak-pihak mengikatkan diri itu tidak jelas untúk apa.

Dikatakan tidak lengkap, karena definisi tersebut hanya mengacu kepada perjanjian sepihak saja. Hal ini terlihat dari rumusan kalimat "yang terjadi antara satu orang atau lebih mengikatkan dirinya kepada 'satu orang atau lebih. Mengingat kelemahan tersebut, J. Satrio mengusulkan agar rumusan dirubah menjadi: atau di mana kedua belah pihak saling mengikatkan diri. ${ }^{18}$

Dikatakan terlalu luas, karena rumusan: suatu perbuatan hukum dapat mencakup perbuatan hukum (zaakwaarneming), dan perbuatan melawan hukum (onrechtmatigedaad). Suatu perbuatan melawan hukum memang dapat timbul karena perbuatan manusia dan sebagai akibatnya timbul suatu perikatan, yakni adanya kewajiban untuk melakukan transaksi tertentu yang berwujud ganti rugi kepada orang yang dirugikan.
Perbuatan melawan hukum jelas tidak didasarkan atau timbul dari perjanjian. ${ }^{19}$ Perjanjian kawin dalam hukum keluarga atau perkawinanpun berdasarkan rumusan perjanjian dalam Pasal 1313 KUHPerdata tersebut dapat digolongkan sebagai perjanjian. ${ }^{20}$

J. Satrio ${ }^{21}$ membedakan perjanjian dalam arti luas dan sempit. Dalam arti luas, suatu perjanjian berarti setiap perjanjian yang menimbulkan akibat hukum sebagai yang dikehendaki (atau dianggap dikehendaki) oleh para pihak, termasuk di dalamnya perkawinan, perjanjian kawin, dan lain-lain. Sedangkan dalam arti sempit, perjanjian hanya ditujukan kepada hubungan-hubungan hukum dalam lapangan harta kekayaan saja sebagaimana diatur Buku III KUHPerdata.

Dalam upaya memperbaiki kelemahan definisi di atas, Pasal 6213 ayat (1) Kitab Undang-Undang Hukum Perdata Belanda (BW Baru) mendefenisikan pejjanjian sebagai suatu perbuatan hukum yang terjadi antara satu orang atau lebih mengikatkan dirinya kepada satu orang atau lebih atau di mana keduanya saling mengikatkan dirinya. ${ }^{22}$

Di dalam sistem common law ada pembedaan antara contract dan agreement.

. ${ }^{18} \mathrm{~J}$. Satrio. 1995. Hukum Perikatan, Perikatan yang Lahir dari Perjanjian, Buku 1. Bandung: Citra Aditya Bakti. HIm 27.

${ }^{18} \mathrm{Ibid}$. Him 24.

${ }^{20}$ Mariam Darus Badrulzaman. Op.Cit. Hilm 18.

${ }^{21} \mathrm{~J}$. Satrio. Op.Cit. HIm $28-30$.

${ }^{22}$ Naskah aslinya menyebutkan:"Een overeenkomst in de zijn van dze titel isn een meerzijdige rechtshandeling, waarbij een of meer partijen jegens een of meer andere een verbintenis aangaan". Lihat R.J.Q Klomp (red). 1997. Burgerlijk Wetboek, Boken $1 \mathrm{t} / \mathrm{m}$ 8. Ars Aequi Libri, nijmegen. P.P.C. Haanappel dan Ejan Mackaay menerjemahkannya ke dalam bahasa Inggris sebagai berikut: $A$ contract in this sense of this title is a multiltaral juridical act whreby one or more parties assume an obligation toward one or more other 
Semua kontrak adalah agreement, tetapi tidak semua agreements adalah kontrak. ${ }^{23}$ American Restatement of Contract (second) mendefinisikan kontrak sebagai a promise or set of promises for the breach of which the law give a remedy or the performance of which the law in some why recognized a duty. ${ }^{24}$ Substansi definsi kontrak di atas adalah adanya mutual agreement atau persetujuan (assent) para pihak yang menciptakan kewajiban yang dilaksanakan atau kewajiban yang memiliki kekuatan hukum. ${ }^{25}$

Agreement sendiri merupakan a coming together of mind; a coming together in opinion or determination; the comming together in accord of two minds on a given proposition... The union on two or more minds in a thing done or to be done; a mutual assents to do thing ... agreement is a broader term e.g. an agreement might lack an eseential element of contract. ${ }^{26}$

Agreement atau persetujuan dapat dipahami sebagai suatu perjumpaan nalar, yang lebih merupakan perjumpaan pendapat atau ketetapan maksud. Persetujuan adalah perjumpaan dari dua atau lebih nalar tentang suatu hal yang telah dilakukan atau akan dilakukan. Secara lebih luas persetujuan dapat ditafsirkan sebagai suatu kesepakatan timbal balik untuk melakukan sesuatu.
Dengan demikian agreement merupakan esensi kontrak. Agreement mensyaratkan adanya offerdan acceptance oleh para pihak. ${ }^{27}$ Offer sendiri menurut American Restatement Contract (second), adalah manifestasi kehendak untuk mengadakan transaksi yang dilakukan agar orang lain tahu bahwa persetujuan pada transaksi itu diharapkan dan hal itu akan menutup transaksi itu. ${ }^{28}$ Adapun acceptance adalah manifestasi dari persetujuan pihak offere (orang menawarkan) terhadap penawaran yang bersangkutan. Singkatnya offer dan acceptance sepadan dengan istilah ijab dan kabul. Prinsip semacam ini di Indonesia dikenal sebagai prinsip persesuaian kehendak.

Persyaratan Perjanjian menurut Pasal 1320 KUHPerdata. Pasal 1320 KUHPerdata' menentukan adanya 4 (empat) syarat sahnya suatu perjanjian, yakni:

1. sepakat bagi mereka yang mengikatkan dirinya;

2. cakap untuk membuat suatu perikatan;

3. suatu hal tertentu; dan

4. suatu sebab (causa) yang halal.

Persyaratan tersebut di atas berkenaan baik mengenai subyek maupun obyek perjanjian. Persyaratan yang pertama dan kedua berkenaan dengan subyek perjanjian. Sedangkan

parties. Lihat P.P.P. Haanappel dan Ejan Makaay. 1990. Nieuw Nderlands Burgerlijk Wetboek, Het Vermogenrechts. Deventer: Kluwer. HIm 325.

${ }^{23}$ Walter Woon. 1995. Basic Business Law in Singapore. New York: Prentice Hall. HIm 27.

${ }^{24}$ Ronald A. Anderson. 1987. Business Law. Ohio: South-Western Publishing Co, Cincinnati. HIm 186. 25 /bid.

${ }^{26}$ Budiono Kusumohamidjojo. 1998. Dasar-Dasar Merancang Kontrak. Jakarta: Grasindo. HIm 5.

${ }^{27}$ Catherine Tay Swee Kian dan Tang See Chim. 1993. Contract Law. Singapore: Times Books International. HIm 20.

${ }^{28}$ Henry R. Cheseeman. 1995. Business Law: The Legal, Ethical, and International Environtment. New Jersey: Prentice Hall Engelwood Cliffs. HIm 168. 
persyaratan yang ketiga dan keempat berkenaan dengan obyek perjanjian.

Pembedaan kedua persyaratan tersebut dikaitkan pula dengan masalah batal demi hukumnya (nieteg $=$ null and void $=$ void $a b$ initio) dan dapat dibatalkannya (vernietigbaar= voidable). Perjanjian yang batal demi hukum adalah perjanjian yang sejak semula sudah batal, hukum menganggap perjanjian tersebut tidak pernah ada. Sedangkan perjanjian yang dapat dibatalkan adaiah sepanjang perjanjian tersebut belum atau tidak dibatalkan pengadilan, maka perjanjian yang bersangkutan masih terus berlaku.

Pakar hukum Indonesia umumnya berpendapat bahwa apabila persyaratan subyektif perjanjian (kata sepakat dan kecakapan untuk melakukan perikatan) tidak dipenuhi tidak mengakibatkan batalnya perjanjian, tetapi hanya dapat dibatalkan melalui putusan pengadilan. Sedangkan apabila persyaratan yang menyangkut obyek perjanjian (suatu hal tertentu dan adanya causa hukum yang halal) tidak dipenuhi, maka perjanjian tersebut batal demi hukum.

\section{A. Kata Sepakat}

Kata sepakat di dalam perjanjian pada dasarnya adalah pertemuan atau persesuaian kehendak antara para pihak di dalam perjanjian. Seseorang dikatakan memberikan persetujuannya atau kesepakatannya (toestemming) jikà ia memang menghendaki apa yang disepakati. ${ }^{29}$.

Mariam Darus Badrulzaman melukiskan pengertian sepakat sebagai persyaratan kehendak yang disetujui (overeenstemende wilsverklaring) antar pihak-pihak. Pernyataan pihak yang menawarkan dinamakan tawaran (offerte). Pernyataan pihak yang menerima penawaran dinamakan akseptasi (accceptatie). ${ }^{30}$

Dengan demikian, penawaran dan akseptasi merupakan unsur yang sangat penting dalam menentukan lahisnya perjanjian. Namun demikian, KUHPerdata Indonesia, bahkan KUHPerdata Negeri Belanda (Baru) sendiri tidak menjelaskan atau tidak memberikan patokan sejauhmana suatu penawaran dan/atau akseptasi itu mengikat." Artikel 217 ayat (2) BW Baru Belanda hanya menyebutkan: Een overeenkomst komt tot stand door een aanbood en de aanvaarding daarvan. ${ }^{32}$

Mengingat tidak adanya definisi penawaran tersebut, Rutten mendefinisikan penawaran sebagai suatu usul untuk menutup perjanjian yang ditujukan kepada pihak lawan janjinya, usul mana telah dirumuskan sedemikian rupa sehingga penerimaan usul itu langsung menimbulkan perjanjian. ${ }^{33}$

Pernyataan kehendak tersebut harus merupakan pernyataan bahwa ia menghendaki timbulnya hubungan hukum. Kèsesuaian

${ }^{29}$ J. Satrio. 1995. Op. Cit. Bandung: Citra Adiyta Bakti. Him 164.

${ }^{30}$ Mariam Darus Badrulzaman. 1994. Op.Cit. Bandung: Alumni. HIm 24.

${ }^{31}$ J. Jatrio. Op.Cit. Hlm 166.

${ }^{32}$ Terjemahan bahasa Inggrisnya adalah: A contract is formed by an offer and its acceptance. Lihat terjemahan BWBaru dalam Bahasa Inggris dan Perancis, P.P.C. Haanappel dan Ejan Mackaay. 1990. Nieuw Nederlands Burgerlijk Wetboek: Het Vermogenrechts. Deventer: Kluwer.

${ }^{33} \mathrm{~J}$. Satrio. Op.Cit. HIm 166. 
kehendak antara dua saja belum melahirkan perjanjian, karena kehendak tersebut harus dinyatakan, harus nyata bagi pihak yang lain, dan harus dapat dimengerti oleh pihak lain. Apabila pihak yang lain tersebut telah menyatakan menerima atau menyetujuinya, maka timbullah kata sepakat.

Dengan demikian, orang dapat mengatakan bahwa suatu pernyataan adalah suatu penawaran apabila hal itu sampai pada orang yang diberikan penawaran, sedang pernyataan itu sendiri haruslah diartikan sebagai suatu tanda yang dapat diketahui dan dimengerti oleh lawan janjinya. Konsekuensinya, jika terjadi karena penawaran itu diterima secara keliru -ada akseptasi yang menyimpang dari penawarannya - maka pada dasarnya tidak lahir perjanjian. ${ }^{34}$

- J. Satrio menyebutkan ada beberapa cara mengemukakan kehendak tersebut, yakni: ${ }^{35}$

1. secara tégàs;

2. secara tertulis;

a. dengan akte otentik

b. dengan akte di bawah tangan

3. secara lisan;

-" dengan tanda

4. secara diam-diam.

Sekalipun undang-undang tidak secara tegas mengatakan, tetapi dari ketentuan- ketentuan yang ada, antara lain Pasal 1320 jo Pasal 1338 KUHPerdata; dapat disimpulkan bahwa pada asasnya, kecuali ditentukan lain, undang-undang tidak menentukan cara orang menyatakan kehendak. ${ }^{36}$

Contoh pernyataan kehendak yang dinyatakan dengan tanda-tanda dapat dilihat dalam proses pelelangan, orang dapat menyatakan persetujuan atau ketidaksetujuannya hanya dengan melakukan gerakan tubuh baik melalui tangan ataupun kepala.

Seseorang yang menjual barang melalui mesin otomatis diam-diam menawarkan suatu barang. Dengan diam-diam ia menyatakan kehendaknya. Demikian pula tukang becaknya yang mengayuh becaknya menyusuri jalan; diam-diam menawarkan perjanjian pengangkutan. Yang dinamakan diam-diam menyatakan kehendaknya bisa meliputi baik menawarkan maupun akseptasinya, dan karenanya ada kemungkinan bahwa suatu perjanjian terjadi karena ditutup secara diam-diam oleh para pihak. ${ }^{37}$

Berkaitan dengan kesepakatan dan lahimya perjanjian, Mariam Darus Badrulzaman mengemukan beberapa teori mengenai lahirnya perjanjian tersebut. ${ }^{38}$

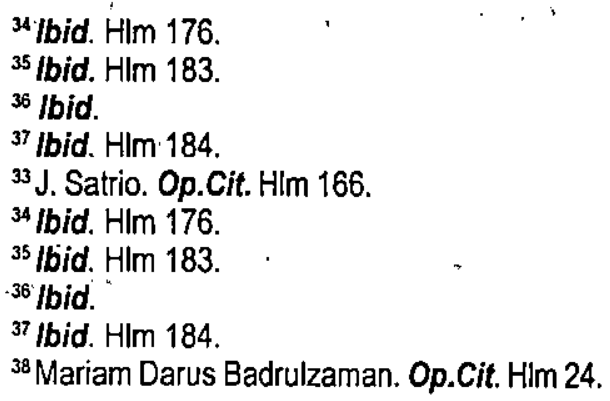


1. Teori kehendak (wilstheorie) mengajarkan bahwa kesepakatan terjadi pada saat kehendak pihak penerima dinyatakan, misalnya dengan menuliskan surat;

2. Teori pengiriman (verzendtheorie) mengajarkan bahwa kesepakatan terjadi pada saat kehendak yang dinyatakan itu dikirim oleh pihak yang menerima tawaran;

3. Teori pengetahuan (vernemingstheorie) mengajarkan bahwa pihak yang menawarkan seharusnya sudah mengetahui bahwa tawarannya sudah diterima; dan

4. Teori kepercayaan (vertrowenstheorie) mengajarkan bahwa kesepakatan itu terjadi pada saat pemyataan kehendak dianggap layak diterima oleh pihak yang menawarkan.

Suatu perjanjian dapat mengandung cacat kehendak atau kata sepakat dianggap tidak ada jika terjadi hal-hal yang disebut di bawah ini, yaitu:

1. adanya kesesatan atau kekeliruan (dwaling);

2. adanya paksaan (dwang);

3. adanya penipuan (bedrog); dan

4. dalam perkembangan lebih lanjut, dikenal pula cacat kehendak yang lain, yakni penyalahgunaan keadaan (mis-bruik van omstandigheiden): ${ }^{39}$

Jadi, sekarang ini dikenal adanya empat kelompok bentuk cacat kehendak.
Menurut doktrin dan yurisprudensi, temyata perjanjian-perjanjian yang mengandung cacat seperti itu tetap mengikat para pihak, hanya saja, pihak yang merasakan telah memberikan pernyataan yang mengandung cacat tersebut dapat memintakan pembatalan perjanjian. Sehubungan dengan ini, Pasal $1321 \mathrm{KUHPerdata}$ menyatakan:

"Jika di dalam suatu perjanjian terdapat kekhilafan, paksaan atau penipuan, maka berarti di dalam perjanjian itu terdapat cacat pada kesepakatan antar para pihak dan karenanya perjanjian itu dapat dibatalkan".

Persyaratan adanya kata sepakat dalam perjanjian tersebut di dalam sistem common law dikenal dengan istilah agreement atau assent. Section 23 American Restatement (second) menyatakan bahwa hal yang penting dalam suatu transaksi adalah bahwa masingmasing pihak menyatakan persetujuannya sesuai dengan pernyataan pihak lawannya.

Esensi atau substansi kontrak adalah adanya mutual agreement atau esent yang menciptakan kewajiban untuk dilaksanakan atau kewajiban yang memiliki kekuatan hukum. ${ }^{40}$ Agreement sendiri adalah a coming together of mind; a coming together in opinion or determination; the coming together in accord of two minds on a given proposition... The union on two or more minds in a thing done or to be done; a mutual assent to do thing ... agreement is a broader term e.g. an agree-

39 J. Satrio. Op.Cit. Him 268. Lihat Juga Mariam Darus Badrulzaman. Op.Cit. Hlm 26.

${ }^{40}$ Ronald A. Anderson. 1987. Business Law, Ohio: South Western Publlishing Co. HIm 186. Lihat juga Chaterine Tay Swee Kian dan Tang See Chim. 1993. Contract Law. Singapore: Times Books International. Him 20. 
ment might lack an essential element of contract. $^{41}$

Agreement dapat dipahami sebagai suatu perjumpaan nalar, yang lebih merupakan perjumpaan atau ketetapan maksud. Persetujuan adalah perjumpaan dari dua atau lebih nalar tentang suatu hal yang telah dilakukan atau akan dilakukan. Secara lebih luas, agreement dapat ditafsirkan sebagai suatu kesepakatan timbal balik untuk melaksanakan sesuatu. Agreement itu sendiri mensyaratkan adanya offer dan acceptance oleh para pihak.

Menurut American Restatement Contract (second), offer adalah manifestasi kehendak untuk.mengadakan transaksi ${ }^{42}$ yang dilakukan agar orang lain tahu bahwa persetujuan di dalam transaksi itu diharapkan dan hal itu akan menutup transaksi tersebut. ${ }^{43}$ Offer ini adalah pernyataan mengenai syarat-syarat yang dikehendaki offeror (pihak yang menawarkan) supaya mengikat. Jika tawaran itu diterima oleh pihak offeree (pihak yang menerima tawaran) sebagaimana adanya, maka lahirlah perjanjian. Dengan perkataan lain, offer merupakan tawaran yang diajukan seseorang kepada pihak lawannya dengan suatu pemberitahuan bahwa dia berkemauan untuk terikat terhadap tawarannya.

Pihak offeror dapat menyampaikan tawarannya tersebut kepada orang tertentu (particular persons) atau kelompok tertentu (group of persons) atau ke seluruh dunia (the whole world). "Tawaran yang ditawarkan kepada orang tertentu, misalnya A menawarkan untuk menjual mobilnya kepada $B$ dengan harga dinyatakan. Suatu tawaran boleh dilakukan terhadap kelompok tertentu, setiap anggota kelompok tersebut boleh menerima, karena tawaran itu hanya terbuka bagi anggota kelompok tersebut. Kadang-kadang suatu tawaran dilakukan ke seluruh dunia di mana pemilik menawarkan hadiah kepada siapa saja yang dapat menemukan atau mengembalikan' burung Kenarinya yang hilang. ${ }^{45}$

Tidak semua penawaran memiliki konsekuensi hukum. Ada beberapa penawaran yang tidak termasuk penawaran dalam arti hukum sebagaimana dijelaskan di bawah ini: ${ }^{45}$

\section{Ajakan untuk Melayani Semata}

Ini adalah suatu indikasi bahwa seseorang berkehendak untuk melakukan perundingan, tetapi tidak berkehendak untuk terikat dengan

${ }^{41}$ Budiono Kusumohamidjojo. 1988. Dasar-Dasar Merancang Kontrak. Jakarta: Grasindo. Hlm 5.

${ }^{42}$ Transaksi adalah suatu tindakan yang menimbulkan tindakan timbal balik atau penyelenggaraan bisnis. Transaksi juga mancakup unsur-unsur merundingkan, mengelola, memproses sesuatu yang telah diputuskan. Transaksi adalah sesuatu yang telah terjadi; di mana suatu kausa (sebab) tindakan telah timbul. Suatu transaksi hanya dapat timbul apabila ada persetujuan di antara para pihak. Lihat $/$ bid. HIm 4.

${ }^{43}$ Henry R. Cheseeman. 1995. Business Law: The Legal, Ethical, and International Environment. New Jersey: Prentice Hall. HIm 168.

${ }^{4}$ Roberth Upex. 1991. Davies on Contract. London: Sweet \& Maxwell. HIm 7.

${ }^{45}$ S.B. Marsh dan J. Soulsby. 1978. Business Law. McGraw-Hill Book Co. Sebagaimana diterjemahkan Abdul Kadir Muhammad. Op.Cit. Bandung: Alumni. HIm 108.

${ }^{46}$ lbid. 
syarat-syarat yang disebutkan. Daftar barang dagangan atau surat edaran yang mengiklankan barang-barang untuk dijual merupakan ajakan semacam itu. Cara yang sama juga berlaku apabila suatu perusahaan besar mengundang para penawar untuk menyediakan barang atau jasa.

Suatu selebaran perusahaan yang mengundang penanam modal untuk membeli sahamnya, juga merupakan ajakan untuk melayani dan bukan suatu tawaran, sebab perusahaan tersebut masih dapat menolak membagikan sahamnya kepada mereka yang mengajukan permohonan untuk memperolehnya.

Pada umumnya apabila seseorang menunjukkan bahwa berkehendak untuk berhubungan dengan seseorang seperti contoh di atas tadi, ini akan diperlakukan sebagai ajakan untuk melayani sematamata. Sebaliknya,akan menjadi suatu situasi yang tidak mungkin misalnya, jika suatu iklan untuk menjual sebuah mobil diadakan sebagai tawaran tetap, 20 penerimaan yang masuk. Hanya dalam hal di mana pemasang iklan dengan jelas bermaksud untuk terikat, iklan itu akan diperlakukan sebagai tawaran tetàp. Mungkin contoh ajakan paling tepat adalah barang-barang dalam etalase toko yang disertai label harga yang ditempelkan. Pelayan toko tidak berusaha untuk menjual barang-barang itu. Barang-barang tersebut hanya dipamerkan untuk menarik calon pembeli untuk membeli barang yang bersangkutan sesuai dengan harga yang diperlihatkan. Pelayan toko selalu dapat menolak, walaupun dengan jelas ia jarang berbuat hal yang demikian.

\section{Isapan-Jempol atau Bualan Semata}

Dalam hal ini tidak seorangpun yang akan memperhatikan secara serius, seperti merek yang tertera pada paket bahwa "merek $X$ mencuci paling bersih" tidak dianggap sebagai tawaran tetap. Dalam perkara Canwill v Carbolic Smoke Ball, para tergugat mengiklankan bahwa mereka akan membayar setiap orang yang terkena influenza setelah memakai bolabola asap mereka, dan sebagai bukti kejujuran mereka, mereka telah menyediakan uang sebesar $1.000,00$ found di sebuah bank. Ny. Carwill mengikuti petunjuk mereka, tetapi masih terkena influenza, dan akhirnya menuntut ganti rugi sebasar 100,00 found. Pengadilan memutuskan bahwa iklan tersebut adalah tawaran. Orang bisa tertarik dan menerima janji itu secara serius, dan menganggap pemasang iklan tersebut itu bermiaksud untuk terikat dengan syarat-syarat yang dinyatakannya itu.

\section{Pernyataan Kehendak}

Pernyataan kehendak juga tidak bermaksud membentuk dasar perjanjian, dan bukan suatu tawaran. Dalam perkara Harriss $\checkmark$ Nickerson, suatu jual lelang diiklankan dan kemudian dibatalkan. Penggugat yang telah berangkat ke tempat pelelangan itu menuntut ongkos perjalanannya sebagai ganti rugi. Gugatannya tidak dikabulkan pengadilan, karena iklan itu bukanlah tawaran yang dapat diterimanya dengan melakukan perjalanan itu.

\section{Semata-mata Memberikan Informasi}

Dalam perkara Harvey v Facey, penggugat mengirim telegram yang isinya: Maukah anda menjual kepada kami Bumper Hall pen dengan harga terendah? Jawabannya: Harga 
terendah 900 found. Menurut pengadilan, Jawaban tersebut oleh pengadilan dianggap hanya sebagai jawaban terhadap permohonan untuk memperoleh informasi, bukan suatu tawaran yang dapat diterima.

Bila suatu penawaran ditentukan berakhimya, maka penawaran akan berakhir sesuai dengan jangka waktu yang ditetapkan. Namun demikian, selama jangka waktu yang ditetapkan itu belum tiba, dan pihak yang ditawarkan (offeree) belum menyatakan penerimaannya, maka pihak yang menawarkan (offeror) dapat menariknya ${ }^{47}$ Apabila penawaran tidak disertai jangka waktu berakhirnya, maka penawaran akan berakhir sebatas waktu yang layak yang bergantung pada jenis perjanjian dan putusan hakim. The Uniform Commercial Court Code (UCC) section 2-205 menetapkan bahwa penawaran seorang pedagang (merchant) dengan tertulis dan ditandatangani, maka penawaran itu tidak dapat ditarik kembali untuk jangka waktu yang ditetapkan atau tidak ada jangka waktu yang ditetapkannya, maka penawaran itu tidak dapat ditarik untuk jangka waktu yang sepatutnya yang dalam setiap peristiwa tidak boleh melebihi jangka waktu tiga bulan. ${ }^{48}$

Penawaran selalu dapat ditarik kembali setiap saat asal saja belum ada penerimaan (acceptance) dari pihak lawan. American Restatement Contract (second) telah mendefinisikan penerimaan (acceptance) sebagai manifestation of assent by the offeree to the term of the offer in manner invited or require by the offer as measured by the objective theory of contract. ${ }^{49}$ Sir William Anson secara lebih singkat juga merumuskan penerimaan sebagai ekspresi yang dilakukan dengan kata-kata atau tingkah laku dari persetujuan terhadap term dari penawaran dengan cara yang digambarkan atau dïndikasikan oleh phak yang menawarkan..$^{50}$

Cara (manner) penerimaan dapat dilakukan dengan perkataan lisan, atau tulisan, dapat pula dengan perbuatan dari pihak yang ditawari untuk melaksanakan perbuatan khusus yang diperlukan oleh pihak yang menawarkan. Persetujuan yang berupa sikap semata-mata tidaklah cukup, juga tidak mungkin dalam hukum Inggris melepaskan penerimaan itu sama sekali. Harus ada suatu perbuatan penerimaan yang positif, dan diam semata tidaklah cukup. ${ }^{51}$

Dalam perkara Felhouse $v$ Bindley, perundingan terjadi mengenai harga seekor Kuda. Penggugat akhimya menulis "kalàu saya tidak mendengar lebih banyak tentang dia, saya perhitungkan Kuda milik saya seharga 30.15 found. Tergugat tidak menjawab. Pengadilan memutuskan bahwa walaupun ia telah bermaksud untuk menerima dan menjual pada harga tersebut, diam tidak menjawab itu tidak dapat dianggap sebagai penerimaan, dan oleh karenanya tidak terjadi perjanjian jual-beli. ${ }^{52}$

${ }^{47}$ Haridjan Rusli. 1993. Hukum Perjanjian Indonesia dan Common Law. Jakarta: Pustaka Sinar Harapan.HIm 55.

${ }^{48}$ lbid.

${ }^{49}$ Henry C. Cheseeman. Op.Cit. HIm 177.

${ }^{50}$ A. G. Guest, (ed). 1979. Anson's Law of Contract. Oxford: Clarendon Press. HIm 34.

${ }^{51}$ Abdul Kadir Muhammad. Op.Cit. HIm 115.

${ }^{52} \mathrm{lbid}$. 
Secara umum pengadilan common law tidak ingin membebankan pihak yang menerima penawaran untuk memberitahukan pengiriman penerimaannya, tétapi apabila pihak yang menerima penawaran menyadari bahwa pengiriman yang dilakukannya tidak dapat diketahui pihak yang menawarkan, maka pihak yang menerima penawarannya harus memberitahukan kepada pihak yang menawarkan apa yang dilakukannya sehubungan dengan penerimaan dari pihak yang menawarkan itu. ${ }^{53}$

\section{B. Kecakapan untuk Membuat Perikatan}

Syarat sahnya perjanjian yang kedua menurut Pasal 1320 KUHPerdata adalah kecakapan untuk membuat perikatan (om eene verbintenis aan te gaan). Di sini terjadi percampuradukan penggunaan istilah perikatan dan perjanjian.

Dari kata "membuat" perikatan dan perjanjian dapat disimpulkan adanya unsur "niat" (sengaja). Hal yang demikian itu dapat disimpulkan cocok untuk perjanjian yang merupakan tindakan hukum. Apalagi karena unsur tersebut dicantumkan sebagai unsur sahnya perjanjian, maka tidak mungkin tertuju kepada perikatan yang timbul karena undangundang. Menurut J. Satrio, istilah yang tepat untuk menyebut syaratnya perjanjian yang kedua ini adalah: Kecakapan untuk membuat perjanjian. ${ }^{54}$

Pasal 1329 KUHPerdata menyatakan bahwa setiap orang adalah cakap untuk membuat perjanjian, kecuali apabila menurut undang-undang dinyatakan tidak cakap. Kemudian Pasal 1330 menyatakan bahwa ada beberapa orang tidak cakap untuk membuat perjanjian, yakni:

1. orang yang belum dewasa;

2. mereka yang ditaruh di bawah pengampuan; dán

3. orang-orang perempuian, dalam hal-hal yang ditetapkan oleh undang-undang dan pada umumnya semua orang kepada siapa undang-undang telah melarang membuat perjanjian tertentu.

Seseorang dikatakan belum dewasa menurut Pasal 330 KUHPerdata jika belum mencapai umur 21 tahun. Seseorang dikatakan dewasa jika telah berumur 21 tahun atau berumur kurang dari 21 tahun, tetapi telah menikah.

Dalam perkembangannya, berdasar $P$ asal 47 dan 50 UU No. 1 Tahun 1974 kedewasaan seseorang ditentukan bahwa anak berada di bawah kekúasaan orang tua atau wali sampai umur 18 tahun.

Selanjutnya Mahkamah Agung melalui Putusan No. 447/Sip/1976 tanggal 13 Oktober 1976 menyatakan bahwa dengan berlakunya UU No. 1 Tahun 1974, maka batas seseorang berada di bawah kekuasaan perwalian adalah 18 tahun, bukan 21 tahun.

Dewasa ini di Belanda kedewasaan juga ditentukan tidak lagi 21 tahun atau telah menikah, tetapi 18 tahun atau telah menikah. Hal tersebut dapat dilihat dari Pasal 233;BW (Baru) Belanda yang menyebutkan: "Minderjarigen zijn, zij, die de ouderdom van cahtien

${ }^{53}$ Haridjan Rusli. Op.Cit. HIm 61 - 62.

${ }^{54}$ J. Satrio. 1995. Hukum Perikatan, Perikatan yang Lahir dari Perjanjian, Buku II. Bandung Citra Adiyta Bakti. HIm 2. 
jaren niet hebben bereikt en niet gehuwd of geregistreerd zijn gewest of met toepassing van artikel 253 ha meerderjarig zijn verklaard". Henry R. Cheseeman ${ }^{55}$ menjelaskan bahwa di dalam sistem common law, seseorang dikatakan belum dewasa jika belum berumur 18 tahun (bagi wanita) dan 21 tahun (bagi pria). Namun dalam perkembangannya, umumnya negaranegara bagian di Amerika Serikat telah mensepakati bahwa kedewasaan tersebut ditentukan jika seseorang telah berumur 18 tahun yang berlaku baik bagi wanita maupun pria.

Seseorang yang telah dewasa dapat tidak cakap melakukan pejjanjian, jika yang bersangkutan diletakkan di bawah pengampuan (curatele atau conservatorship). Seseorang dapat diletakkan di bawah pengampuan jika yang bersangkutan gila, dungu (onnoozelheid), mata gelap (razemij), lemah akal (zwakheid van vermogens) atau juga pemboros. Orang yang demikian itu tidak menggunakan akal sehatnya, dan oleh karenanya dapat merugikan dirinya sendiri.

Pengampuan tidak terjadi demi hukum. Pengampuan tersebut harus berdasarkan putusan Pengadilan Negeri dan diumumkan dalam Berita Negara.

Berkaitan dengan perempuan yang telah bersuami dan melakukan suatu perjanjian, Mahkamah Agung melalui Surat Edarannya (SEMA) Nomor 3 Tahun 1963 menetapkan bahwa perempuan demikian itu tetap cakap melakukan perjanjian. Pasal 31 ayat (2) UU No. 1 Tahun 1974 menentukan hal yang sama. Pasal 31sub 2 UU No. 1 Tahun 1974 menentukan bahwa baik suami maupun isteri berhak melakukan perbuatan hukum.
Seseorang yang telah dinyatakan pailit juga tidak cakap untuk melakukan perikatan tertentu. Seseorang yang telah dinyatakan pailit untuk membuat perikatan yang menyangkut harta kekayaannya. la hanya boleh melakukan perikatan yang menguntungkan budel pailit, dan itu pun harus sepengetahuan kuratornya.

\section{Suatu Hal Tertentu}

Syarat sahnya perjanjian yang ketiga adalah adanya suatu hal tertentu (een bepaald onderwerp). Pasal 1333 KUHPerdata menentukan bahwa suatu perjanjian harus mempunyai pokok suatu benda (zaak) yang paling sedikit dapat ditentukan jenisnya.

Suatu perjanjian harus memiliki obyek tertentu. Suatu perjanjian haruslah mengenai suatu hal tertentu (certainty of terms), berarti bahwa apa yang diperjanjikan, yakni hak dan kewajiban kedua belah pihak. Barang yang dimaksudkan dalam perjanjian paling sedikit dapat ditentukan jenisnya.

Istilah barang dimaksud di sini apa yang dalam bahasa Belanda disebut sebagai zaak. Zaak dalam bahasa Belanda tidak hanya berarti barang dalam arti sempit, tetapi juga berarti yang lebih luas lagi, yakni pokok persoalan. Oleh karena itu, obyek perjanjian tidak hanya berupa benda, tetapi juga bisa berupa jasa.

J. Satrio menyimpulkan bahwa yang dimaksud dengan suatu hal tertentu dalam perjanjian adalah obyek prestasi perjanjian. Isi prestasi tersebut harus tertentu atau paling sedikit dapat ditentukan jenisnya. ${ }^{56}$

${ }^{55}$ Henry R. Cheseeman. Op.Cit. HIm 197.

${ }^{58} \mathrm{~J}$. Satrio. Op.Cit. HIm 41. 
KUHPerdata menentukan bahwa barang yang dimaksud tidak harus disebutkan, asalkan nanti dapat dihitung atau ditentukan. Misalnya mengenai perjanjian "panen Tembakau dari suatu ladang dalam tahun berikutnya" adalah sah. Namun, perjanjian jual beli "Teh untuk seribu rupiah" tanpa penjelasaan lebih lanjut, harus dianggap tidak cukup jelas.

American Restatement Contract (second) section 33 menyatakan bahwa pokok perjanjian (term) menyatakan bahwa walaupun suatu pernyataan dimaksudkan untuk dianggap sebagai penawaran, hal ini belum dapat diterima langsung menjadi perjanjian, bila pokok perjanjian tidak tentu.

Black Law Dictionary mendefinisikan term sebagai persyaratan, kewajiban, hak, harga, dan lain-lain yang ditetapkan dalam perjanjian dan dokumen. American Restatement Contract (second) section 33 sub section 2 menjelaskan bahwa bila pokok perjanjian itu mencakup dasar untuk menyatakan adanya wanprestasi dan untuk memberikan ganti rugi yang layak.

\section{Kausa Hukum yang Halal}

Syarat sahnya perjanjian yang keempat adalah adanya kausa hukum yang halal. Kata kausa yang diterjemahkan dari kata oorzaak (Belanda) atau causa (Latin) bukan berarti sesuatu yang menyebabkan seseorang membuat perjanjian, tetapi mengacu kepada isi dan tujuan perjanjian itu sendiri. Misalnya dalam perjanjian jual beli, isi dan tujuan atau kausanya adalah pihak yang satu menghendaki hak milik suatu barang, sedangkan pihak lainnya menghendaki uang.

Berdasarkan penjelasan di atas, maka apabila seseorang membeli pisau di suatu toko dengan maksud membunuh orang, maka jual beli tersebut mempunyai kausa yang halal. Akan tetapi, apabila maksud membunuh tersebut dituangkan di dalam perjanjian, misalnya penjual pisau menyatakan hanya bersedia menjual pisaunya jika pembeli membunuh orang dengan pisaunya, di sini tidak ada kausa hukum yang halal.

Menurut Pasal 1335 jo 1337 KUHPerdata bahwa suatu kausa dinyatakan terlarang jika bertentangan dengan undang-undang, kesusilaan, dan ketertiban umum.

Suatu kausa dikatakan bertentangan dengan undang-undang, jika kausa di dalam perjanjian yang bersangkutan isinya bertentangan dengan undang-undang yang berlaku.Untuk menentukan apakah suatu kausa perjanjian bertentangan dengan kesusilaan (goede zeden) bukanlah masalah yang mudah, karena istilah kesusilaan tersebut sangat abstrak, yang isinya bisa berbeda-beda antara daerah yang satu dan daerah atau antara kelompok masyarakat yang satu dan lainnya. Selain itu penilaian orang terhadap kesusilaan dapat pula berubah-ubah sesuai dengan perkembangan zaman. J. Satrio mempermasalahkan, apakah kausa hanya tidak boleh bertentangan dengan kesusilaan yang bersifat umum ataukah hanya dalam lingkup yang terbatas. Dalam hal ini terdapat dua pendapat. Pendapat yang satu hanya mau menerima "kesusilaan" dalam lapangan, yakni kalau ia merupakan penerapan moral umum dalam kalangan terbatas atau hubungan hukum tertentu. Pendapat yang lain, yakni pendapat yang lebih luas, yang mau menerima "kesusilaan" dalam kalangan yang terbatas, asal tidak bertentangan dengan kesusilaan umum. Brakel lebih setuju dengan pendapat yang sempit, alasan sulit menuntut hakim agar ia menerapkan norma moral, yang 
tidak diyakininya, karena ia sendiri bukan berasal dari kalangan di mana moral itu berlaku, dan oleh karenanya tidak sesuai dengan kesadaran moralnya. ${ }^{57}$

Kausa hukum dalam perjanjian yang terlarang juga apabila bertentangan dengan ketertiban umum. J. Satrio memaknai ketertiban umum sebagai hal-hal yang berkaitan dengan masalah kepentingan umum, keamanan negara, keresahan dalam masyarakat, dan karenanya dikatakan mengenai masalah ketatanegaraan. ${ }^{58}$ Di dalam konteks Hukum Perdata Internasional (HPI), ketertiban umum dapat dimaknai sebagai sendi-sendi atau asas-asas hukum suatu negara. ${ }^{59}$

Kausa hukum yang halal ini di dalam sistem common law dikenal dengan istilah legality yang dikaitkan dengan public policy. Suatu kontrak dapat menjadi tidak sah (illegal) jika bertentangan dengan public policy. Walaupun sampai sekarang belum ada definisi public policy yang diterima secara luas, pengadilan memutuskan bahwa suatu kontrak bertentangan dengan public policy jika berdampak negatif pada masyarakat atau mengganggu keamanan dan kesejahteraan masyarakat (public's safety and welfare). ${ }^{60}$

Apabila kajian teoritis perjanjian ini dijadikan pola pendekatan dalam menganalisis apakah absah kontrak elektronik yang dilakukan dalam sistem pembayaran. Hal ini tentunya dapat saja dilakukan.
Seperti diketahui adanya ketentuan hukum dimaksudkan untuk mempertegas hubunganhubungan hukum. Begitupun halnya dalam transaksi e-commerce, khususnya dalam sistem pembayaran pola ini sangat dibutuhkan.

Sistem pembayaran intemet yang sekarang dijalankan mempunyai dua metode. Metodemetode itu di antaranya:61

1. Perintah melalui Telpon (Phone in Order), Banyak perusahaan yang hanya menggunakan Web sebagai sebuah papan pengumuman dari perusahaan dan produknya. Jika seseorang menginginkan untuk memerintah items mereka memberikan sejumlah nomor panggil 1-800. Seorang operator hanya memproses perintah itu apabila nasabah melihat iklan di TV atau Majalah.

2. Perintah melalui Kartu Kredit (Credit Card Orders), nasabah yang menggunakan Web dengan basis bentuk CGI dengan perintah pengisian informasi nasabah dan menunjukkan nomor kartu kredit mereka. SLL sebagai teknologi yang melindungi nomor kartu.

Dalam kesempatan ini akan dicoba dipertegas hubungan hukum yang ada dengan menggunakan kartu kredit sebagai alat pembayaran. Menurut Millet $\mathrm{J}$ berpendapàt

${ }^{57}$ lbid. HIm 110.

${ }^{58} \mathrm{lbid}$. HIm 127.

${ }^{59}$ Ridwan Khairandy, et.al. 1999. Pengantar Hukum Perdata Internasional. Yogyakarta: Pusat Studi Hukum Faklultas Hukum Ull - Gamma Media. HIm 90.

${ }^{60}$ Henry R. Cheseeman. Op.Cit. HIm 205.

${ }^{61}$ Scott Richards. "Electronic Money/lnternet Payment Systems. " www.yahoo.com. 
bahwa pada penggunaan kartu kredit, secara serentak bekerja tiga perjanjian yang'satu sama lain saling terpisah, yaitu:

1. Perjanjian penjual barang dan atau jasa antara pedagang dan pemegang kartu.

2. Pejjanjian antara pedagang dan perusahaan peneribit kartu, yang berdasarkan perjanjian itu pedagang yang bersangkutan setuju untuk menerima pembayaran yang menggunakan kartu itu.

3. Perjanjian antara perusahaan penerbit kartu dan pemegang kartu, atau pemegang rekening, yang berdasarkan perjanjian itu pemegang kartu menyetujui untuk melunasi pembayaran yang telah dilakukan oleh penerbit kartu kepada penjual barang dan/atau, jasa berkenaan dengan penggunaan kartu oleh, pemegang kartu yang bersangkutan.

Kontrak pengadaan pembayaran dengan kartu kredit merupakan kontrak Bisnis ke Bisnis (Business to Business Contract). Kalau dilihat kontrak pengadaan pembayaran dapat saja dilakukan oleh para pihak yang beda kewarganegaraannya atau negara, maka sebelum sampai kepada analisis diberlakukannya hukum kontrak Indonesia. Ada baiknya dalam penjelasan ini dikemukakan tiga teori yang memungkinkan dijadikan landasan untuk menentukan lex loci contractus.

Di negara-negara civil law bilamana kedua belah pihak dalam suatu kontrak tidak saling bertemu muka, maka digunakan teori deklarasi (theory of declaration). Menurut teori ini, penerimaan terhadap penawaran oleh yang ditawari harus dinyatakan (declared). Surat pernyataan penerimaan penawaran harus sampai kepada pihak yang menawarkan:dan penerimaan penawaran tersebut harus diketahui oleh pihak yang menawarkan. ${ }^{62}$

Di lain pihak di negara-negara common law teori yang digunakan mail box theory, yaitu salah satu pihak yang mengirimkan surat yang berisi penerimaan atas penawaran yang diajukan oleh pihak lainnya. Dengan mengacu kepada teori ini, berkaitan dengan kepentingan nasabah dapat digunakan kedua teori' ini. ${ }^{63}$.

Dua teori ini sebenarnya baru dapat diimplementasikan apabila para pihak dalam transaksi pembayaran di internet.menganut pada sistem hukum yang sama. Persoalannya sekarang bagaimana apabila para pihak berada dalam sistem hukum yang berbeda. Untuk menjawab pertanyaan ini, sebenarnya dapat dipergunakan teori the most characteristic connection. Dalam teori ini kewajiban untuk melakukan suatu prestasi yang paling karakteristik tolak ukur penentuan hukum yang akan mengatur perjanjian itu. Dalam setiap kontrak dapat dilihat pihak mana yang melakukan prestasi yang paling karakteristik dan hukum dari pihak yang melakukan prestasi yang paling karakteristik ini hukum yang dianggap harus dipergunakan; karena hukum inilah yang terberat dan yang. paling sewajamya dipergunakan. Maka berdasarkan pada teori ini dikaitkan dengan transakși pembayaran internet dalam masalah perlindungan nasabah. Sebenarnya hukum penyedia jasa transaksi pembayaran internetlah:yang akan digunakan. Kalau penyedia jasa transaksi pembayaran internet ada di Indonesia, di mana sistem hukumnya menganut sistem civil law,

${ }^{62}$ Ridwan Khairandy,et,al. Op. Cit. Him. 115.

${ }^{63}$ Ibid. 
maka aturan-aturan hukum kontrak Indonesialah yang akan dipakai sebagaimana telah dijelaskan di atas. Tetapi apabila penyedia jasa transaksi pembayaran itu adalah pihak asing dan menganut sistem common law, maka hukum kontrak yang berdasarkan common law itu yang akan dipergunakan.

Khusus untuk Masyarakat Ekonomi Eropa, mereka telah memberikan garis-garis petunjuk kepada para negara anggotanya guna menjamin terlaksananya dengan tertib dan guna menghilangkan keragu-raguan dalam proses terciptanya penawaran dan penerimaan dalam masalah kontrak melalui media elektronik. Semula petunjuknya dikenal sebagai sistem " 3 klik". Pertama, setelah calon pembeli melihat di layar komputernya adanya penawaran dari calon penjual (klik pertama), maka si calon pembeli memberikan penerimaan terhadap penawaran tersebut (klik kedua). ${ }^{64}$

Di samping adanya proses (klik) penawaran dan penerimaan, masih disyaratkan adanya peneguhan dan persetujuan dari calon penjual kepada calon pembeli perihal diterimanya penerimaan dari calon pembeli (klik ketiga). Dengan demikian, adanya penawaran dan penerimaan melalui media elektronik dapat dikukuhkan. ${ }^{65}$

Sebagai perbandingan lain, untuk kedepannya mengenai pengaturan kontrak elektronik, maka dapat dilihat pada ketentuan Model Law on Electronic Commerce yang sudah dikeluarkan oleh PBB. Pasal 15 Model Law on Electronic Commerce menyatakan:

(1) Kecuali diatur secara lain oleh originator dan addresse, saat suatu data massage dikirim(dispatch) adalah pada saat ia memasuki suatu sistem informasi di luar kontrol dari originator atau orang lain yang mengirimkan data tersebut untuk kepentingan originator.

(2) Kecuali diatur secara lain antara originator dan addresse, waktu diterimanya suatu data massages ditentukan sebagai berikut:

a. Kalau seorang addresse sudah menentukan suatu informasi sebagai tujuan dikirimnya data massages, saat diterimanya adalah:

1) Pada saat data massages tersebut memasuki sistem informasi tertentu (designated system information) yang dituju; atau

2) Apabila suatu data massages dikirimkan ke suatu informasi yang bukanlah suatu sistem informasi yang tertentu (designated system information), maka waktunya adalah pada pesan tersebut diterima oleh addresse;

b. Apabila suatu data tidak mempunyai suatu sistem informasi tertentu (designated system information), maka saat diterima adalah pada saat data massages memasuki sistem informasi dari addrese.

\section{Digital Signature sebagai Alat Bukti}

Pembuktian menurut Pitlo adalah suatu cara yang dilakukan oleh suatu pihak atas fakta dan hak yang berhubungan dengan

${ }^{64}$ Setiawan. "Electronic Commerce Tinjauan Dari Segi Hukum Kontrak Suatu Catatan Singkat." Varia Peradilan Majalah Hukum Tahun XV. No. 176. Mei 2000. HIm.115.

65 Ibid. 
kepentingannya. Subekti berpendapat bahwa yang dimaksud dengan membuktikan adalah meyakinkan hakim tentang kebenaran dalil atau dalil yang dikemukakan dalam "suatu persengketaan. Sementara menurut ketentuan Pasal 163 HIR (283 RBG) menyatakan setiap orang yang mendalilkan bahwa ia mempinyai suatu hak, atau guna meneguhkan haknya sendiri maupun membantah hak orang lain, menunjuk pada suatu peristiwa diwajibkan membuktikan adanya hak atau peristiwa tersebut. Dari sini ada dua aspek yang perlu diperhatikan dalam pembuktian yakni menyangkut dalil peristiwa dan adanya hak.

Proses pembuktian baru terjadi apabila ada sengketa di antara para pihak. Sengketa itu sendiri biasanya penyelesaiannya ditentukan oleh salah satu klausula dalam kontrak. Umumnya penyelesaian itu dapat melalui lembaga litigasi atau non-litigasi. Khusus untuk pembahasan pembuktian ini diarahkan pada pola penyelesaian di lembaga peradilan.

Dalam konteks hukum Indonesia mengenai pembuktian mengacu pada hukum acara perdata. Dasar beracara dalam perkara perdata pengaturannya ditentukan dalam HIR (Herzien Inlands Reglements) atau RIB (Reglemen Indonesia yang Diperbaharui).

Dalam Pasal 164 HIR (284 RBG) dan 1866 KUHPerdata ada lima alat bukti yang dapat diajukan dalam proses persidangan. Alat bukti itu adalah:

1. Bukti tulisan

2. Bukti dengan saksi

3. Persangkaan-persangkaan

4. Pengakuan

5. Sumpah
Apabila melihat pada ketentuan ini dan kemungkinan digital signature digunakan. sebagai alat bukti tidak dimungkinkan' atau akan ditolak baik oleh hakim maupun pihak lawan. Hal ini karena ternyata pembuktian yang dikehendaki berdasarkan pada ketentuan di atas mensyaratkan bahwa alat bukti itu berupa tulisan, sementara digital signature sifatnya tanpa kertas bahkan merupakan scripless transaction.

Ketidakmungkinan digital signature dipakai sebagai alat bukti tidaklah absolut, namun relatif sifatnya. Sebab.menurut hukum acara perdata Indonesia, apabila ada sengketa, kemudian sengketa itu diserahkan pada hakim dalam penyelesaiannya, maka hakim tidak boleh menolak perkara tersebut dengan alasan tidak ada hukumnya (asas ius curianovif). Artinya jika terjadi sengketa dalam transaksi pembayaran elektronis antara para pihak, maka hakim pun wajib untuk menerimanya.

Dengan alasan ini pula sebenarnya hakim di Indonesia diberi keleluasaan untuk menemukan hukum. Seandainya terjadi sengketa dalam transaksi pembayaran, maka sebenamya dengan metode penemuan hukum hakim dapat saja menganggap bahwa digital signature sebagai alat bukti. Dengan catatan hakim harus dibekali. pengetahuan yang cukup mengenai skema sistem pembayarañ elektronis. Setidaknya mengetahui mekanisme sistem pembayaran elektronis yang sëcara keseluruhan tidak berbasis kertas. Metode yang digunakan adalah metode interpretâsi analogis dan interpretasi ekstensif. ${ }^{66}$

Interpretasi analogis merupakan penemuan hukum yang dilakukan oleh hakim dengan

${ }^{6}$ Sudjkno Mertokusumo. 1999. Mengenal Hukum Suatu Pengantar. Yogyakarta: Liberty. Him. 160-162. 
cara memberi penafsiran pada suatu peraturan hukum dengan memberi kias pada kata-kata dalam peraturan tersebut sesuai dengan asas hukumnya, sehingga suatu peristiwa yang sebenarnya tidak' dapat dimasukkan kemudian dianggap sesuai dengan bunyi peraturan tersebut. Contohnya analogi mengenai aliran listrik dan data elektronik. Dalam kaitan ini digital signature sebagai data elektronik belum ada peraturannya secara khusus; maka dalam proses pembuktiannya dapat dilakukan melalui metode interpretasi analogis.

- Interpretasi ekstensif dilampaui batasbatas yang ditetapkan oleh interpretasi gramatikal.$^{67}$ Melalui metode interpretasi ekstensif ini, 'maka makna' tertulis sebagaimana yang dimaksudkan dalam ketentuan alat bukti menurut hukum acara Indonesia dapat diperluas.

Metode interpretasi ekstensif ini seharusnya diawali dulu dengan memberikan penjelasan terhadap kata tertulis. Berdasarkan Pasal 1904 BW dikenal pembagian kategori tertulis terdiri dari:

a. Otentik

b. Bawah tangan

Pengaturan lebih lanjut berkaitan dengan kata tertulis ini terdapat juga pada Pasal 1905 1920 BW yang membaginya lagi dalam dua bagian: a. Akta

b. Bukan Akta

Dari sini dapat diketahui bahwa pengaturan/pembagian kata tertulis ini dalam hukum Indonesia masih ada kerancuhan, namun demikian untuk menengahi perbedaan ini dapatlah dik'emukakan pendapat Pitlo, salah satu Sarjana Hukum asal Belanda yang. memadukan perbedaan di atas. Menurutnya katagori tertulis itu meliputi:68

1. Akta Otentik

2. Akta Bawah Tangan

3. Bukan Akta

Kategori yang akan dijelaskan di sini hanyalah menyangkut poin 1, yakni akta otentik. Sesuatu dapat dikatakan akta otentik apabila akta tersebut dibuat, berdasarkan undangundang dan dihadapan seorang pejabat yang berwenang (PPAT).

Dalam hal sistem pembayaran elektronis, tidak ada alat bukti lain yang dapat digunakan selain data elektronik/digital berupa digital signature. Untuk dapat diklasifikasikan dalam bentuk tertulis banyak cara yang dapat dilakukan. Salah satu cara tersebut dengan membuat suatu printout atau copy dari pesan yang 'masih berbentuk elektronik. Hukum Indonesia ternyata belum memungkinkan untuk menggunakan cara ini: Namun, hukum

${ }^{66}$ Sudikno Mertokusumo. 1999. Mengenal Hukum Suatu Pengantar. Yogyakarta: Liberty. Hlm. 160-162.

67 Menurut Sudikno Mertokusuko interpretasi gramatikal adalah merupakan cara penafsiran atau penjelàsan yang paling sederhana untuk mengetahui makna ketentuan undang-undang dengan menguraikannya menurut bahasa, susunan kata atau bunyinya.

${ }^{68}$ Arrianto Muki Wibowo. "Kerangka Hukum Digital Signature Dalam Electronic Commerce." Makalah disampaikan pada Masyarakat Telekomunikasi Indonesia. Diselenggarakan oleh UI, Depok Jawa Barat. Juni 1999.HIm.26. 
Indonesia malah merupakan kebalikannya peralihan itu terjadi dari yang tertulis ke bentuk data elektronis. Hal ini dapat ditemukan pada Pasal 12 UU No. 8 Tahun 1987 tentang Dokumen Perusahaan yang berbunyi:

(1) Dokumen perusahaan dapat dialihkan ke dalam mikrofilm atau media lainnya.

(2) Pengalihan dokumen perusahaan ke dalam mikrofilm atau media lainnya sebagaimana dimaksud dalam ayat (1) dapat dilakukan sejak dokumen tersebut dibuat atau diterima oleh perusahaan yang bersangkutan.

(3) Dalam mengalihkan dokumen perusahaan sebagaimana dimaksud dalam ayat (1), pimpinan perusahaan wajib mempertimbangkan kegunaan naskah asli dokumen yang perlu tetap disimpan karena mengandung nilai tertentu demi kepentingan perusahaan atau kepentingan nasional.

(4) Dalam hal dokumen perusahaan yang dialihkan ke dalam mikrofilm atau media lainnya adalah naskah asli yang mempunyai kekuatan pembuktian otentik dan masih mengandung kepentingan hukum tertentu, pimpinan perusahaán wajib tetap menyimpan naskah asli tersebut.

Setelah proses pengalihan dilakukan untuk menjadikan dokumen perusahaan ini mempunyai kekuatan alat bukti, maka perlu ada proses legalisasi. Pengaturan legalisasi ini terdapat pada ketentuan Pasal 13 dan Pasal 14 UU No. 8 Tahun 1997 tentang. Dokumen Perusahaan. Pasal 13 UU No. 8 Tahun 1997 tentang Dokumen Perusahaan berbunyi: "setiap pengalihan dokumen perusahaan sebagaimana dimaksud dalam Pasal 12 ayat (1) wajib dilegalisasi." Pasal 14 UU No. 8 Tahun 1997 berbunyi:

(1) Legalisasi sebagaimana dimaksud dalam Pasal 1.3 dilakukan oleh pimpinan perusahaan atau pejabat yang ditunjuk di lingkungan perusahaan yang bersangkutan, dengan dibuat berita acara...

(2) Berita acara yang dimaksud dalam ayat (1) sekurang-kurangnya memuat:

a. keterangan tempat, hari, tanggal, bulan dan tahun dilakukannya legalisasi;

b. keterangan bahwa pengalihan dokumen perusahaan yang dibuat di atas kertas ke dalam mikrofilm atau media lainnya telah dilakukan sesuai dengan aslinya; dan

c. tandatangan dan nama jelas pejabat yang bersangkutan

Setelah proses pengalihan dan legalisasi, maka dokumen perusahan tersebut dinyatakan sebagai alat bukti yang sah. Hal ini dapat didasarkan pada Pasal 15 UU No. 8. Tahun 1997 yang berbunyi:

(1) Dokumen perusahaain yang telah dimuat dalam mikrofilm atau mediā lainnya sebagaimana dimaksud dalam Pasal 12 ayat (1) dan atau hasil cetakannya merupakan alat bukti yang sah.

(2) Apabila dianggap perlu dalam hạ tertentu dan untuk keperluan tertentu dapat dilakukan legalisasi terhadap hasil cetak dokumen perusahaan yang telah dimuat dalam mikrofilm atau media lainnya. 
Meskipun dapat saja hakim mengatakan bahwa digital signature dapat dijadikan sebagai alat bukti sah melalui metode interpretasi. ${ }^{69}$ Akan tetapi, untuk kepentingan jangka panjang sangat diperlukan sekali aturan hukum yang mengatur secara tegas berhubungan dengan digital signature.

Untuk memformulasikan aturan hukum, Model Law on Electronic Commerce layak untuk dijadikan acuan dalam pengaturan digital signature ini. Pasal 5 Uncitral Model Law on Electronic ' Commerce menyatakan bahwa data massages mempunyai kekuatan hukum dan dapat dijalankan secara hukum. Hal ini dikarenakan pesan-pesan ini mempunyai sifatsifat yang dipunyai oleh kontrak-kontrak konvensional yang biasa dikenal. Sehingga berdasarkan pasal ini data massages ini mempunyai kekuatan yuridis. Seluruh data massages dikirim oleh para pihak dengan menggunakan digital signature. Pesan ini senantiasa dapat diakses (dapat dilihat), dapat diperiksa orisinalitasnya (dengan mengecek masseges digest), dapat mengidentifikasikan penandatangannya (ditandatangani dengan menggunakan kunci privat penandatangan).

Model Law menyatakan beberapa persyaratan agar suatu pesan dapat masuk ke dalam kriteria "writing". Kriteria yang dipakai adalah: ${ }^{70}$
1. Adanya bukti yang cukup yang dapat membuktikan adanya kata sepakat dari para pihak;

2. Memberitahukan kepada para pihak bahwa perbuatan yang dilakukannya ini mempunyai akibat hukum;

3. Mempertahankan keberadaan dokumen tersebut (dokumentasi) untuk suatu jangka waktu tertentu;

4. Memungkinkan dilakukannya otentifikasi terhadap dokumen tersebut dengan menggunakan tandatangan yang ada;

5. Memudahkan verifikasi ýang dilakukan oleh pemerintah atau untuk kepentingan pengadilan;

6. Untuk memudahkan para pihak untuk menutup perjanjian (finalize) dan menyediakan bukti bagi telah adanya kesepakatan itu;

7. Untuk memastikan data atau informasi yang ada belum pernah diubah/dirusak sejak ia pertama kali dibuat (dengan kata lain disini ditekankan pada faktor integrity dari data tersebut);

8. Digital signature yang terdapat dalam pesan atau data massages ini adalah dibuat dalam suatu jangka waktu yang terdapat di dalam certificate. Jadi selama certificate itu masih valid (sah). Digital signature tersebut dibuat dengan

\footnotetext{
${ }^{69}$ Kelemahan dari metode interpretasi terkadang banyak interpretasi hukum yang dilakukan oleh hakim tidak konsisten. Hal ini setidaknya dapat dilihat pada beberapa kasus di luar negeri menyangkut tulisan dan tanda tangan. Contoh kasus Roos v. Aloi, 127 Misc. $2 d 864,487$ N. Y.S. $2 d 637$ (Sup. Ct. 1985) yang memutuskan bahwa rekaman tipe merupakan kontrak lisan dan bukan tertulis di bawah the statue of frauds. Sementara masih dalam kasus Ellis Canning Co. V. Bernstein, 348F. Supp. 1212 (D. Colo. 1972) memutuskan bahwa rekaman tipe dari kontrak lisan adalah berupa tulisan di bawah the statue of frauds. Benjamin Wright \& Jane K. Winn. The Law of Electronic Commerce. Third Edition. New York: Aspen Law \& Business. Hlm. 14-5.

${ }^{70}$ Muhammad Aulia Adnan. “Aspek Hukum Protokol Pembayaran Visa/Mastercard Secure Electronic Transaction (SET)." Skripsi. Fakultas Hukum UI Depok Jawa Barat. 2001. HIm. 57-68.
} 
menggunakan kunci privat, yaitu pasangan kunci dari kunci publik yang terdapat dalam certificate tersebut. Jangka waktu dari berlakunya certificate itu dapat dilihat di Certificate Practice Statement (CPS) milik issuer dari certificate tersebut, sedangkan untuk mengetahui apakah certificate tersebut masih valid atau tidak dapat dilihat di Certificate Revocation List (CRL). Keberadaan CPS dan CRL adalah sangat penting dalam proses penandatanganan suatu dokumen karena ia akan menentukan apakah dokumentasi tersebut valid atau tidak.

9. Untuk memudahkan pendokumentasian data dalam bentuk tertentu (in tangible form);

10. Digital signature tersebut milik dari orang yang dianggap telah menandatangani (disini ditekankan pada prinsip otentisitas). Berdasarkan hal ini, maka sangat penting untuk menjaga keberadaan kunci privat agar jangan sampai digunakan oleh orang lain yang tidak berhak. Apabila kunci privat itu hilang atau dicuri orang, maka certificate pasangannya harus segera di-revoke. Pemilik kunci yang asli mempunyai kewajiban untuk segera melaporkan peristiwa ini, karena ia dapat diminta pertanggungjawaban atas penggunaan kunci yang tidak pada tempatnya;

11. Digital signature yang diterapkan oleh pemiliknya, diterapkan dengan kesadaran yang penuh dari penandatangan. Penandatangan tersebut harus bebas dari unsur tekanan, paksaan ataupun kekhilafan;

12. Untuk menunjang dilakukannya kontrol dan audit untuk kepentingan akuntasi, pajak dan ketentuan perundangan yang berlaku lainnya.
Pasal 6 menekankan pada keuntungan dari sifat tertulis (writing) untuk maksud dan tujuan saja dan bukan secara umum. Pasal ini menekankan pada.adanya alàt bukti untuk kepentingan pajak dan peraturan perundangundangan lainnya. Pasal ini juga menekankan bahwa data massages tersebut harus dapat dibaca dan digunakan untuk berbagai tujuan: Segala asumsi-asumsi maupun pernyataan yang telah disebut di atas tidak mempunyai kekuatan hukum, apabila bukti sècara teknis bahwa proses yang digunakan untuk memverifikasi digital signature secara teknis tidak secure.

\section{Upaya Penyelesaian Sengketa}

Pelaksanaan sistem pembayaran internet sangat dimungkinkan munculnya sengketa di antara para pihak yang terkait dalam sistem pembayaran ini. Oleh karena itu, penting sekali dilakukan upaya-upaya penyelesaian sengketa, lebih khusus lagi penyelesaian sengketa ini juga dapat dijadikan sebagai instrumen perlindungan bagi nasabah yang melakukan transaksi pembayaran melalui media internet.

Persoalan hukum muncul ketika sengketa dalam sistem pembayaran internet berbenturan dengan isu yurisdiksi hukum. Tetapi, dalam jangka pendek model penyelesaian hukum non penal tradisional, masih sangat memungkinkan. Lembaga hukum yang dapat digunakan untuk penyelesaian sengketa dalam transaksi pembayaran internet melalui lembaga Alternative Dispute Resolution (ADR).

Dalam sudut pandang yang luas $A D R$ meliputi segala cara penyelesaian sengketa di fuar pengadilan, secara garis besar, ADR dapat diklasifikasikan ke dalam negosiasi, good offices, mediasi, konsiliasi, arbitrase dan 
kombinasi dari kelima media tersebut: minitrial. Summary jury trial, rent-a-judge, med-arb."

Penyelesaian sengketa dalam transaksi pembayaran internet ini dapat saja dilakukan secara tradisional, misalnya melalui lembaga arbitrase. Untuk dapat dilakukan penyelesaian melalui lembaga arbitrase, maka para pihak harus melihat apakah ada klausul arbitrase. Dalam arti kata selain ada perjanjian pokok yang bersangkutan diikuti atau dilengkapi dengan persetujuan arbitrase. Dari berbagai sumber undang-undang, peraturan dan konvensi internasional ada dijumpai dua bentuk klausul arbitrase. Klausul arbitrase yang dimaksud adalah Pactum de compromittendo dan Akta kompromis." ${ }^{2}$ Pactum de compromitendo adalah para pihak mengikatkan kesepakatan akan menyelesaikan persengketaan yang mungkin timbul melalui forum arbitrase. Pada saat mereka mengikatkan dan menyetujui klausul arbitrase, sama sekali belum terjadi perselisihan. Pengaturan klausul arbitrase ini ada dalam Pasal 615 ayat (3) Rv serta diatur juga dalam Pasal II Konvensi New York 1958.

Tata cara pembuatan klausul Pactum de compromittendo ini dapat dilakukan dengan dua cara, yaitu:

1. Mencantumkan klausul arbitrase yang bersangkutan dalam perjanjian pokok.
2. Pactum de compromittendo dibuat dalam akta tersendiri. Perjanjian arbitrase dalam hal ini tidak langsung digabung menjadi satu dengan perjanjian pokok.

Sementara Akta kompromis adalah sebuah perjanjian arbitrase yang dibuat setelah timbulnya perselisihan antara para pihak. Pengaturannya ada dalam Pasal 618 dan dalam Konvensi New York Pasal II ayat (1).

Bagi Indonesia penyelesaian sengketa transaksi pembayaran internet ini dengan menggunakan lembaga arbitrase sangat dimungkinkan. Alasan hukum yang dapat dikemukakan oleh karena Indonesia telah meratifikasi United Nations Convention on the Recognation and Enforcement Arbitral Award (the New York Convention) dengan Keppres No. 31 Tahun 1981 tentang Ratifikasi atas Konvensi New York. Bila diperhatikan Pasal 2 the New York Convention menyebutkan "terhadap putusan arbitrase yang berada di luar yurisdiksi suatu negara atau arbitrase asing dapat dilakukan penegakan. Dengan diberlakukannya Keppres №. 31 Tahun 1981, maka suatu putusan arbitrase asing dapat dilaksanakan di Indonesia. Mengenai tata cara eksekusi putusan arbitrase asing ini diatur dalam Perma No. 1 Tahun 1990.

${ }^{71}$ Nandang Sutrisno. "Dasar-dasar Penyelesaian Sengketa Alternatif," makalah disampaikan pada Pelatihan Alternative Dispute Resolution (ADR). Diselenggarakan oleh FH UII bekerja sama dengan The Asia Foundation, Yogyakarta $19 \mathrm{~s} / \mathrm{d} 22$ Agustus 1999, Hlm. 5. Lihat juga M. Yahya Harahap, "ADR Merupakan

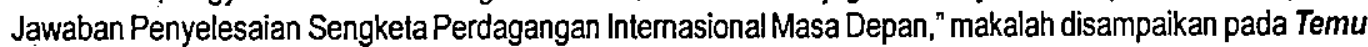
IImiah Nasional Ismahi. Yogyakarta 11-13 April 1995. Lihat Juga William F. Fox, Jr, International Commercial Agreements. Second Edition. Boston: Kluwer Law and Taxation Publisher. HIm. 87-88.

${ }^{72}$ Yahya Harahap.Arbitrase. Jakarta: Pustaka Kartini. 1991. HIm. 100. 
Sesudah dikeluarkannya UU No. 30 Tahun 1999 tentang Arbitrase dan Alternatif Penyelesaian Sengketa, maka pengakuan hukum indonesia terhadap putusan arbitrase asing semakin kuat. Hal itu dibuktikan dengan adanya pengaturan hukum mengenai arbitrase internasional yang diatur dalam Bagian Kedua, Pasal.65 sampai dengan Pasal 69. Secara otomatis pula Keppres No. 31 Tahun 1981 dan Permen No. 1 Tahun 1990 menjadi tidak berlaku.

Pada perkembangannya mekanisme penyelesaian sengketa dengan ADR yang biasanya digunakan dalam sengketa bisnis yang berbasis kertas (tradisional) dapat dipertuas ke transaksi online. Kalau terjadi sengketa nasabah, maka dapat diselesaikan dengan online. Hal ini dapat mengurangi waktu dan biaya $\mathrm{ADR}^{{ }^{i 3}}$ Istilah dari model penyelesaian semacam ini sering disebut ADRonline.

Pendekatan baru ini dibangun dan disediakan agar nasabah lebih fleksibel, tepat waktu dan mekanisme yang efisien sekaligus menekan biaya yang harus dikeluarkan nasabah. Model ini dikembangkan dengan maksud untuk membangun sistem yang dapat memuaskan nasabah, di mana penyelesaian dapat diselesaikan setiap saat.

Model $A D R o n l i n e$ yang dikembangkan sekarang ini banyak mengambil bentuk mediasi. Pertimbangan dengan model mediasi, maka penyelesaian hukum dapat dilaksanakan dengan lebih tepat waktu serta dimungkin adanya efisiensi biaya. Namun demikian, bukan berarti bentuk-bentuk ADR lain tidak dapat digunakan, sesungguhnya bentuk lain pun sebenarnya șama saja.

\section{Simpulan}

Pelaksanaan kontrak pembayaran elektronik (internet) dapat dilaksanakan dengan - menggunakan teori The Most Characteristic Connection. Dengan demikian hukum kontrak Indonesia yang menganut sistem civil law dapat dipergunakan apabila pihak penyedia jasa pembayaran internet berkedudukan di Indonesia, sementara hukum kontrak yang menganut sistem common law pun dapat digunakan juga apabila pihak penyedia jasa pembayaran internet berkedudukan di negara yang menganut sistem common law. Digital signature dipandang dari hukum pembuktian Indonesia tidak dapat dijadikan alat bukti. Oleh karena alat bukti yang dimaksud sifatnyà harus berbentuk tertulis. Pada dasarnya digital signature dapat saja di-printout/copy; namun hukum pembuktian indonesia tidak mengenal perubahan data dari elektronis ke bentuk print out. Justru yang ada adalah sebaliknya. Upaya penyelesaian sengketa dalam. sistem pembayaran internet apabila terjadi sengketa adalah dengan cara melalui lembaga ADR konvensional maupun ADRonline: ב. -

\section{Daftar Pustaka}

"Jurisdiction in Cyberspace," September 1999, www.gip.org/publication/papers/ ipjuris.asp:

Adnan, Muhammad Aulia "Aspek Hukum. Protokol Pembayaran Visa/Mastercard Secure Electronic Tranisaction (SET)." Skripsi. Fakultas Hukum Jawa Barat. 2001.:

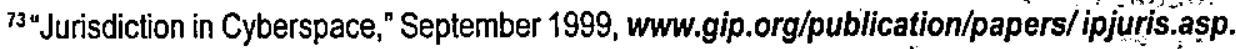


Anderson, Ronald A.. 1987. Business Law. Ohio: South-Western Publishing Co, Cincinnati.

Badrulzaman, Meriam Darus. 1994. Aneka Hukum Bisnis. Bandung: Alumni.

Caldwell, Kave. "Applying Old Law to New Technology." the CommerceNet Newsletter The Public Policy Report. Vol. 2 No. 7 Agustus 2000.

Cheseeman, Henry R.. 1995. Business Law:

The Legal, Ethical, and International Environtment. New Jersey: Prentice Hall, Engelwood Cliffs.

Davidson, Daniels.1997. Comprehensive

Büsiness Law. Boston Massachusets:

Ken Publishing Comp.

Fox, William F. Jr. International Commercial Agreements. Second Edition. Boston: Kluwer Law and Taxation Publisher.

Guest, A.G.'(ed). 1979. Anson's law of Contract. Oxford:Clarendon Press.

Haanappel, P.P.C. dan Ejan Mackaay. 1990. Nieuw Nederlands Burgerlijk Wetboek: Het Vermogenrechts. Deventer: Kluwer.

Harahap, M. Yahya. "ADR Merupakan Jawaban Penyelesaian Sengketa Perdagangan Internasional Masa Depan." Makalah disampaikan pada Temu IImiah Nasional Ismahi. Yogyakarta 11-13 April 1995.

. 1991. Arbitrase. Jakarta: Pustaka Kartini.

Harian Bisnis Indonesia. Tanggal 19 Oktober . 2000.

Haridjan, Rusli. 1993. Hukum Perjanjian Indonesia dan Common Law. Jakarta: Pustaka Sinar Harapan.
Hotchkiss, Carolyn. 1994. International Law For Business. International Edition, Mc. Graw Hill: Business Law Series.

Khairandy, Ridwan et.al. Pengantar Hukum Perdata Internasional. Yogyakarta: Pusat Studi Hukum Faklultas Hukum UII - Gamma Media. 1999.

Kian, Catherine Tay Swee dan Tang See Chim. 1993. Contract Law. Singapore: Times Books International.

Klomp, R.J.Q (red). 1997. Burgerlijk Wetboek, Boken $1 \mathrm{t} / \mathrm{m}$ 8. Ars Aequi Libri, nijmegen.

Kusumohamidjojo, Budiono. 1988. DasarDasar Merancang Kontrak. Jakarta: Grasindo.

Latifulhayat, Atip. "Cyber Law dan Urgensinya Bagi Indonesia." Makalah disampaikan pada seminar tentang Cyber Law. Diselenggarakan oleh Yayasan Cipta Bangsa. Bandung. Tanggal 29 Juli 2000.

Mertokusumo, Sudikno. 1999. Mengenal Hukum Suatu Pengantar. Yogyakarta: Liberty.

Muhammad, Abdul Kadir. 1992. Hukum Perikatan. Bandung: Citra Aditya Bakti.

Naisbitt, John. 1990. Megatrend 2000. Great Britain: Pan Book Published.

Ohmae, Keinichi. 1990. Bonderless World. USA: Business Maknisey Company Printed.

P.P.P. Haanappel dan Ejan Makaay. 1990. Nieuw Nderlands Burgerlijk Wetboek, Het Vermogenrechts. Deventer: Kluwer. 
Budi Agus Riswandi. Aspek Perlindungan Hukum...

Pattiradjawane, Rene L.. "Globalisasi dan Teknologi Menuju Keseimbangan Baru." Harian Kompas. Tanggal 28 April 2000.

Peppard, Joe \& Philip Rowland. The Essence of Business Process Re-Engineering. Yogyakarta: Andi Yogyakarta.

S.B. Marsh dan J. Soulsby. 1978. Business Law. McGraw-Hill Book Co.

Satrio, J. 1995. Hukum Perikatan, Perikatan yang Lahir dari Perjanjian, Buku II. Bandung: Citra Adiyta Bakti.

Satrio, J. 1995. Hukum Perikatan, Perikatan yang Lahir dari Perjanjian, Buku II. Bandung: Citra Aditya Bakti.

1995. Hukum Perikatan, Perikatan yang Lahir dari Perjanjian, Buku 1. Bandung: Citra Aditya Bakti.

Scott Richards. "Electronic Money/Internet Payment Systems." www.yahoo.com.

Setiawan. "Electronic Commerce Tinjauan Dari Segi Hukum Kontrak Suatu Catatan Singkat." Varia Peradilan Majalah Hukum Tahun XV. №. 176, Mei 2000.
Silalahi, Darwin. "Banyak Negara Bersiap dengan Ekonomi Berbasis Internet." Harian Kompas. Tanggal 10 April 2000.

Subekti. 1984. Hukum Perjanjian. Jakarta: Intremasa.

Sutrisno, Nandang. "Dasar-dasar Penyelesaian Sengketa Alternatif." makalah disampaikan pada Pelatihan Alternative Dispute Resolution (ADR). Diselenggarakan oleh FH UII bekerjasama dengan The Asia Foundation. Yogyakarta 19 s/d. 22 Agustus 1999 .

Thompson, William Irwin. 1985. Pasific Shelf. San Fransisco: Series Club Books.

Upex, Roberth. 1991. Davies on Contract, London: Sweet \& Maxwell.

Wibowo, Arrianto Mukti. "Studi Perbandingan Sistem-Sistem Perdagangan DI Internet dan Desain Protokol Cek Bilyet Digital."Laporan Penelitian. Fakultas IImu Komputer UI. Jakarta. 1997.

Woon, Walter. 1995. Basic Business Law in Singapore. New York: Prentice Hall.

Wright, Benjamin \& Jane K. Winn. 2000. The Law of Electronic Commerce. Third Edition. New York: Aspen Law \& Business. 